IMF STAFF DISCUSSION NOTE

Housing Finance and Real-Estate

Booms: A Cross-Country Perspective

Eugenio Cerutti, Jihad Dagher, and Giovanni Dell'Ariccia 


\section{Housing Finance and Real-Estate Booms: A Cross-Country Perspective}

Prepared by Eugenio Cerutti, Jihad Dagher, and Giovanni Dell'Ariccia*

Authorized for distribution by

Olivier Blanchard

DISCLAIMER: This Staff Discussion Note represents the views of the authors and does not necessarily represent IMF views or IMF policy. The views expressed herein should be attributed to the authors and not to the IMF, its Executive Board, or its management. Staff Discussion Notes are published to elicit comments and to further debate.

JEL Classification Numbers: $\quad$ E30, E44, E58, G28

Keywords:

Housing finance, real estate, macroprudential regulation, financial stability, credit booms

ECerutti@imf.org; JDagher@imf.org;

Authors' E-mail Addresses: $\quad$ GDellAriccia@,imf.org

\footnotetext{
* The authors thank Olivier Blanchard, Stijn Claessens, Deniz Igan, Luc Laeven, participants of the IIMB-IMF Conference on Housing Markets, Financial Stability, and Growth (Bangalore, India), and many IMF staff for helpful suggestions and help in the collection of data. Andreas Schaab and Yangfan Sun (data and coding) and Helen Hwang (editing) provided excellent assistance.
} 


\section{CONTENTS}

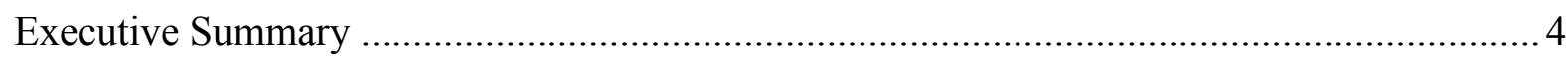

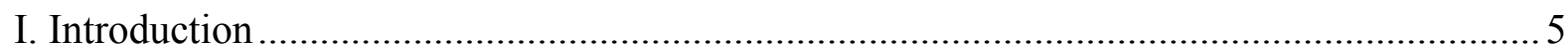

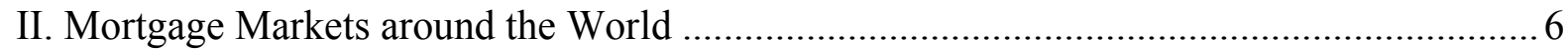

A. Benefits of Deep Mortgage Markets.................................................................................................

B. Factors Associated with Cross-Country Differences in Mortgage Markets.............................9

III. Housing Finance and Real-estate Booms....................................................................... 12

A. Defining and Identifying Credit Booms and Real-estate booms ............................................ 12

B. Interaction between Real-estate booms and Credit Booms ................................................. 15

IV. Policy Implications

Tables

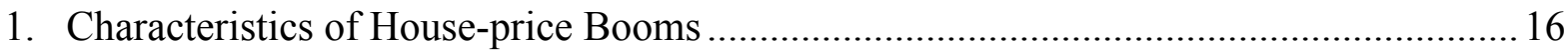

2. Macroeconomic Performance during House-price Booms …………............................... 18

Figures

1. Share of Mortgages to HH Credit and HH Credit to Total Credits, as on 2011_.............. 6

2. The Cross-Section of Outstanding Mortgage Debt/GDP, 2001-2005 Average ................. 7

3. Development Levels and Mortgage Debt/GDP, 2001-05 ........................................ 7

4. Mortgages and Homeownership Across US States ............................................... 8

5. Cross-Country Differences in LTV and Maturities of Mortgages .................................. 10

6. Cross-Country Differences in Mortgage Interest Type and Funding Models................... 11

7. Occurrence of Credit Booms during 1970-2012 ........................................................... 14

8. Occurrence of House-price booms and Credit Booms .............................................. 15

9. Change in House Prices and HH Credit during House-price Booms .............................. 16

10. Average Growth of Real GDP during House-price Booms ........................................ 17

11. Change in House Prices after House-price Booms........................................................ 19

12. Lowest Annual Change in Read GDP after House-price Booms .................................... 19

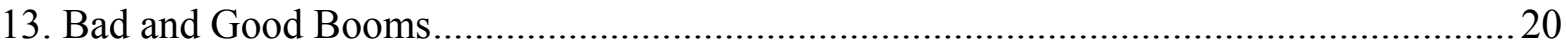

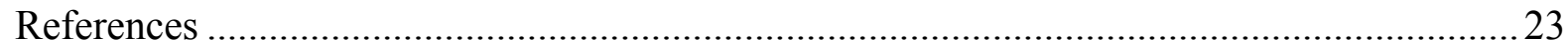




\section{EXECUTIVE SUMMARY}

The global financial crisis highlighted the risks associated with real-estate booms. Before the crisis, mortgage booms both fueled and were supported by rising house prices and economic activity. When that spiral inverted, falling house prices and tightened lending standards led to widespread failures and debt overhang. The result was recessions and massive increases in public debt. Yet at least until the crisis, policies in support of mortgage markets were common and considered essential to promote home ownership, social stability, and ultimately economic growth.

Against this background, this note analyzes the conflict between the objective of increasing access to housing finance and the dangers associated with fast-growing housing credit. This analysis is made possible by a new data set on housing finance characteristics, house prices, and household credit for a sample of more than 50 countries. This detailed cross-country analysis confirms some of the findings of previous work, but also offers new valuable insights from which we draw the following broad conclusions.

First, housing finance characteristics vary widely across countries, and several characteristics are correlated with the relative depth of mortgage markets. Larger loan-to-value ratios (LTVs), larger reliance on wholesale funding, and, to some extent, longer loan maturities are positively correlated, together with institutional quality and macro stability, with the depth of a country's mortgage markets and homeownership rates (with the associated benefits of higher school attainment, higher social capital, lower crime).

Second, some of the housing finance characteristics associated with deeper mortgage markets are also associated with increased risks of crisis. For example, higher LTVs are associated with excessively rapid house-price and credit growth during booms, and wholesale funding is associated with worse outcomes in the aftermath of housing booms.

Third, in this context, both advanced and emerging markets should avoid relaxing house financing standards in order to achieve deeper mortgage markets, and focus first on doing so through improving institutions (for example, legal rights) and the macroeconomic environment.

Fourth, macroprudential policies, and in particular housing finance regulation, should be the first line of defense for handling mortgage market booms, as their narrow focus gives them an advantage over monetary policy. However, their effectiveness beyond the short run has yet to be proven.

Fifth, the role of monetary policy in addressing house-related credit booms should not always be downplayed. Despite the absence of important inflation pressures, about 60 percent of the identified past real-estate booms occurred as a result of, or at the same time as, rapid economic growth and broad high credit growth in the economy. Monetary policy would be a necessary complement of macroprudential measures in those cases.

Finally, dealing effectively with real-estate booms requires a broad mix of policies. Macroprudential and monetary policies are key ingredients, but fiscal incentives and house supply considerations are structural country-specific elements that may bear heavily on the probability of booms occurring and the potential costs of a bust. 


\section{INTRODUCTION}

Housing finance is considered one of the villains of the recent global financial crisis. Before the crisis, booming mortgage markets fueled and were supported by rising house prices and economic activity. When the bubble burst, the spiral inverted. Falling house prices led to household debt overhang and tighter lending standards and led several overleveraged financial institutions into distress. This pattern, most evident in the United States, was present in many countries hard hit by the crisis, with some variation in the underlying drivers and innovations that led to the housing boom. ${ }^{1}$ The recessions and massive increases in public debt that ensued from the fallout in housing led to a renewed debate about financial regulation, consumer protection, and more generally the role asset prices (including the housing market) should play in macro policy decisions.

Yet at least until the crisis, there was a widespread consensus for policies in support of mortgage markets (ranging from interest tax deductibility to publicly supported securitization markets). Many considered access to housing finance as essential to promoting home ownership, which in turn was seen as beneficial to social stability and, ultimately, economic growth.

Then, a tension emerged between increasing access to housing finance and containing the dangers associated with fast-growing mortgage credit. Deeper mortgage markets allow cheaper access to housing credit and promote home ownership. But house-price (real-estate) boom episodes have often ended in busts with important macroeconomic consequences, especially when the boom was financed through fast credit growth. ${ }^{2}$ This note explores this conflict.

The note first analyzes mortgage markets across countries. It documents the heterogeneity of housing finance institutions. And it asks whether housing finance characteristics (for example, mortgage characteristics); institutional factors (for example, rule of law); and/or macro factors (for example, inflation volatility) can predict cross-country differences in mortgage-market depth. Further, it explores the benefits of housing-finance development for home ownership and, more generally, welfare.

The note, then, turns to the interaction of housing finance and the evolution of house prices, more specifically between credit and house-price booms. In particular, we ask whether housing finance characteristics matter in determining the frequency and amplitude of boom-bust

\footnotetext{
${ }^{1}$ For example, while in the United States the rise of securitization and other sophisticated financial instruments, the increased support by government-sponsored agencies to lower-income lending, and the disproportional expansion of nonbank mortgage companies have significantly contributed to the boom, in other countries, such as Ireland, the boom was driven by plain vanilla bank lending with mortgages remaining on banks' balance sheets.

${ }^{2}$ While real-estate booms can pertain to commercial properties rather than housing, in this note we focus on residential housing booms and will use the terms "house-price" booms and "real-estate" booms interchangeably. Also, following the literature we use the term boom and not bubble as the latter term might insinuate a predominant role of non-fundamentals such as speculation.
} 
episodes and the probability that they end up badly (for example, are followed by recessions and/or banking crises). And, in that context, we ask whether one can tell bad booms from good ones, ex-ante. The note exploits a new data set on household- and real-estate-related lending; a step forward relative to most of the existing literature that largely relies on aggregate privatesector credit.

The note approaches these questions with the objective of providing policymakers-who need to detect booms and assess their potential macroeconomic impact — with a set of stylized historical patterns that could inform the appropriate policy response. The rest of the note is structured as follows. Section II describes the characteristics of mortgage markets in a large group of advanced economies and emerging markets, and reviews of the benefits of deeper mortgage markets. Section III identifies real-estate boom and credit boom episodes. It then examines their interaction and macroeconomic impact, and factors that might explain how they end. Section IV concludes with a discussion of the policy implications.

\section{MORTGAGE MARKETS AROUND THE WORLD}

The purchase of a house (typically funded with a mortgage) is the largest transaction of most households' lifetime, and mortgage loans are its main funding tool. This is reflected in the importance of mortgage loans in household credit across countries. In 2011 (the latest year for which we have reliable mortgage data for a broad set of countries), the median share of mortgages in household credit in our sample was about 70 percent, with only six countries below a 40 percent share (Figure 1). Related, countries with a larger share of mortgage to household credit also have a high share in household credit to total credit.

That said, the size of mortgage markets in terms of GDP differs sharply across countries, ranging from below 1 percent in Russia and Turkey to about 80 percent in the Netherlands, New Zealand, and Switzerland (based on 2001-05 averages). Also, while the crisis led to some degree of deleveraging, in most countries, mortgage-to-GDP ratios as of 2011 remained above their average for 2001-05.

Further, their cross-country

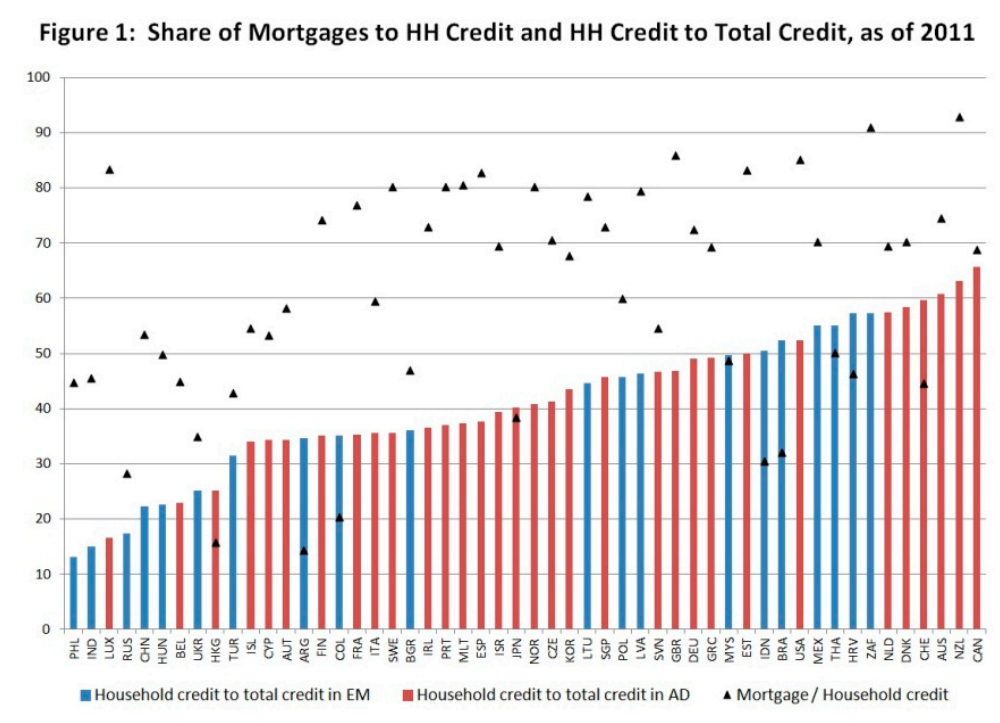
ranking and dispersion did not significantly change over the past few years.

Not surprisingly, this cross-country variation reflects heterogeneity in economic and financial development. In univariate regressions, differences in GDP per capita and the credit-to-GDP ratio explain, respectively, more than 50 and more than 60 percent of the variation in the 


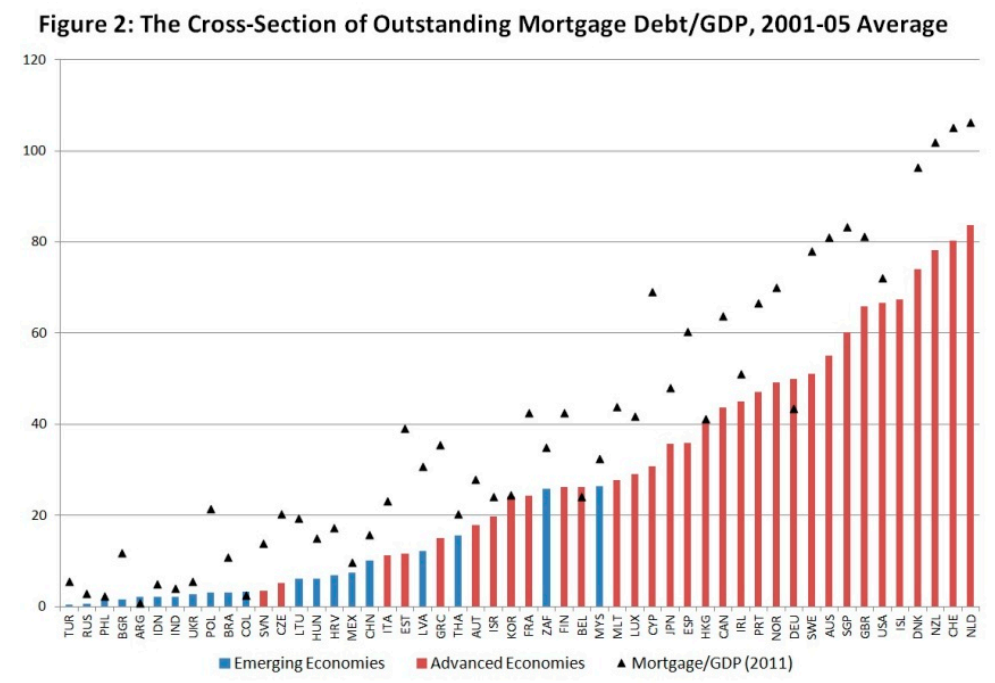

mortgage-to-GDP ratio (Figure 3, left-hand side). Nonetheless, there is still important variation (linked to institutional, cultural, and macroeconomic factors) in the depth of mortgage markets across countries with similar levels of economic development. For example, Austria and the Netherlands have similar GDP per capita, but they exhibit very different mortgage-to-GDP ratios (in 2005, 18 for Austria and 84 percent for Netherlands). This is valid for groups of countries at different income levels as depicted in the right-hand side panel of Figure 3, which divides the sample into three groups (emerging economies, advanced economies with GDP per capita below $\$ 30,000$, and advanced countries with GDP per capita above $\$ 30,000$ ).

The rest of this section reviews the literature on the benefits of deeper mortgage markets in steady state (that is, ignoring the effects of rapid mortgage credit growth - the focus of section III), and how part of the cross-country heterogeneity in mortgage market depth can be related to institutional and macroeconomic factors as well as specific mortgage characteristics.

\section{A. Benefits of Deep Mortgage Markets}

The common wisdom behind government support to housing finance is that deeper mortgage markets benefit homeownership; which in turn is welfare improving. By and large, there is strong support for the argument that deepening and innovations (for example, lower down payment requirements) in mortgage markets favor homeownership. And theoretical as well

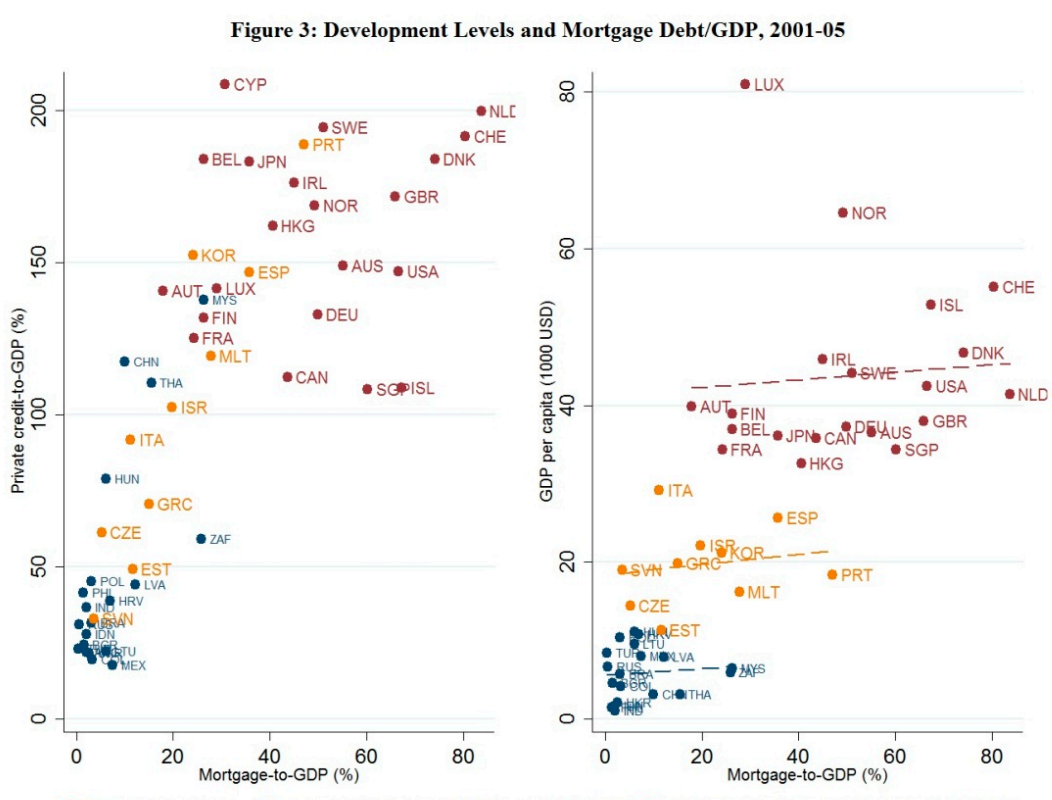


as empirical evidence exists — especially for the United States — for the associated welfare benefits.

Country-specific institutional and cultural factors make it difficult to identify the contribution of housing-finance development to homeownership. In fact, in our sample, cross-country data present a negative relationship between homeownership and mortgage credit. A country-by-country time series approach overcomes some of these difficulties and typically points to a positive relationship between mortgage credit and homeownership. Figure 4 documents this correlation for the case of U.S. states, which share similar institutional and cultural environments (and for which high quality data are available).

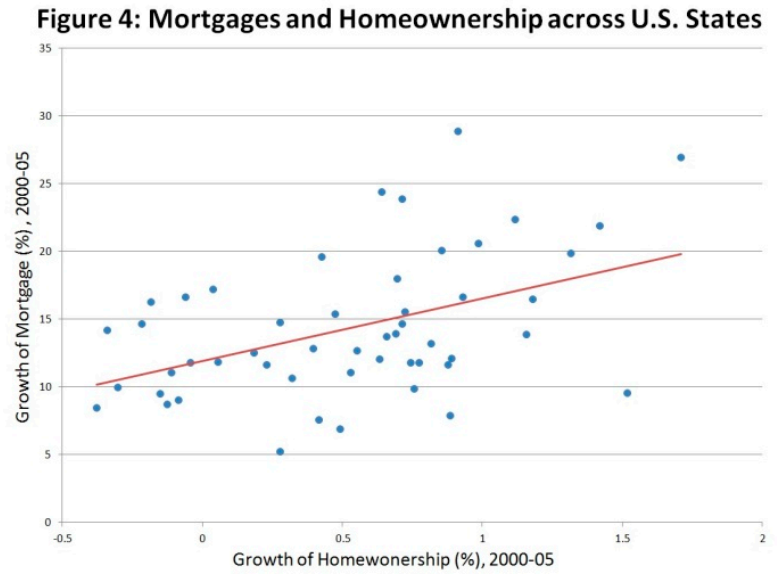

Obviously, even at the single-country level, the relationship could be driven by common trends, and causality is not immediately established. Yet, several papers exploiting microeconomic data find that increases in mortgage availability through innovations and higher LTV have a positive impact on homeownership. For instance, lower down-payment ratios are associated with nontrivially higher homeownership rates for younger households: a decrease in down payment from 40 to 20 percent is associated with an 5 to 8 percentage point increase in the proportion of young households (age 26-35) living in owner-occupied houses (Chiuri and Jappelli, 2003; Chambers, Garriga, and Schlagenhauf, 2009).

Evidence also suggests that homeownership can have a positive effects on welfare factors. In particular, it promotes community investment (for example, DiPasquale and Glaeser, 1999, using data for the United States and Germany) and school attainment (for example, Aaronson, 2000, using data for the United States), and is associated with lower crime incidence and higher levels of life satisfaction (see Rohe and Lindblad, 2013, summarizing U.S. and some European studies).

From an economic perspective, homeownership has been associated with improved saving and investment opportunities for households. Since purchasing a home requires a sizeable downpayment, younger households are more likely to save if homeownership is within reach (Dietz and Haurin, 2003). Further, mortgages commit households to a level of savings that they might not otherwise achieve. This argument weakens somewhat with the advancement of financial innovations that allows households to easily extract equity from their homes.

A second, related, economic argument is that housing is an attractive investment. Indeed, evidence from the United States suggests that the risk-return profile of housing investments 
compares favorably with that of the stock market (Li and Yang, 2010); albeit risk-return profiles on housing vary significantly across regions.

On the negative side, higher homeownership rates are associated with reduced labor mobility (see for example, Dietz and Haurin 2003 for a review). Also, the size of the benefits of homeownership might be smaller than what U.S.-based evidence suggests (see DiPasquale and Glaeser, 1999, on community investment). In countries such as Germany and Switzerlandwhere home ownership rates are low but rental contracts are often long-term — strong communities, low crime, and high social capital are often present. Therefore, policies that increase or even subsidize homeownership (for example, from tax exceptions to government intervention in mortgage markets to increase financial depth) should be based on countryspecific cost-benefit analyses. $^{3}$

\section{B. Factors Associated with Cross-Country Differences in Mortgage Markets}

Mortgage market development is tightly linked to overall financial development, which in turn is related to the quality of institutions and particularly the legal framework that governs financial contracts (see, among others, Beck and Levine, 2008). Macroeconomic factors can also play a role in explaining cross-country differences in housing finance. For example, high inflation volatility (which increases the volatility of returns on nominal contracts) can have an adverse impact on the development of financial markets (Warnock and Warnock, 2008 and 2012).

In addition, specific mortgage-market characteristics may contribute to some of the crosscountry differences in market depth. In some countries, the mortgage market receives little-to-no support from the government while, in others, households are given strong incentives (mainly through tax deductions) that tilt their decisions toward ownership and indebtedness and away from renting. Differences also exist in default laws, the maturity of loans, their relative size, and the types of funding used by lenders. We collected data on the following six house financing characteristics for the countries in our sample for 2005 or the closest year to 2005 for which data are available (See Tables in Annex I).

Maximum Observed LTV: The country-specific upper limit of LTV can serve as a proxy of borrowing constraints (especially for new borrowers). In many instances the maximum observed LTV corresponds to its legal limit (when such limit exists). ${ }^{4}$ As shown in Figure 5, most countries seem to be in the 70-80 and 90-100 LTV buckets. The maximum observed LTV

\footnotetext{
${ }^{3}$ Structural problems in rental markets can favor homeownership. For example, the high and increasing homeownership rate in rapidly urbanizing Northern European countries has been be attributed to an inefficient rental market structure and difficulties in obtaining permits for the development of new rental housing (see, among others, IMF, 2013a).

${ }^{4}$ The legal limit corresponds to the maximum-observed LTV in about half of the countries in the sample. Overall legal limits were not often changed until the late 2000 s.
} 
ranges from 70 percent (Colombia, Hong Kong, and Hungary) to 125 percent (the Netherlands). The median maximum observed LTV is 83 percent.

Term to Maturity: The maturity of mortgage loans varies between 7 years (Turkey) and 45 years (Sweden), with a median of 25 years. This heterogeneity is also likely to be linked to differences in financial development and home affordability.

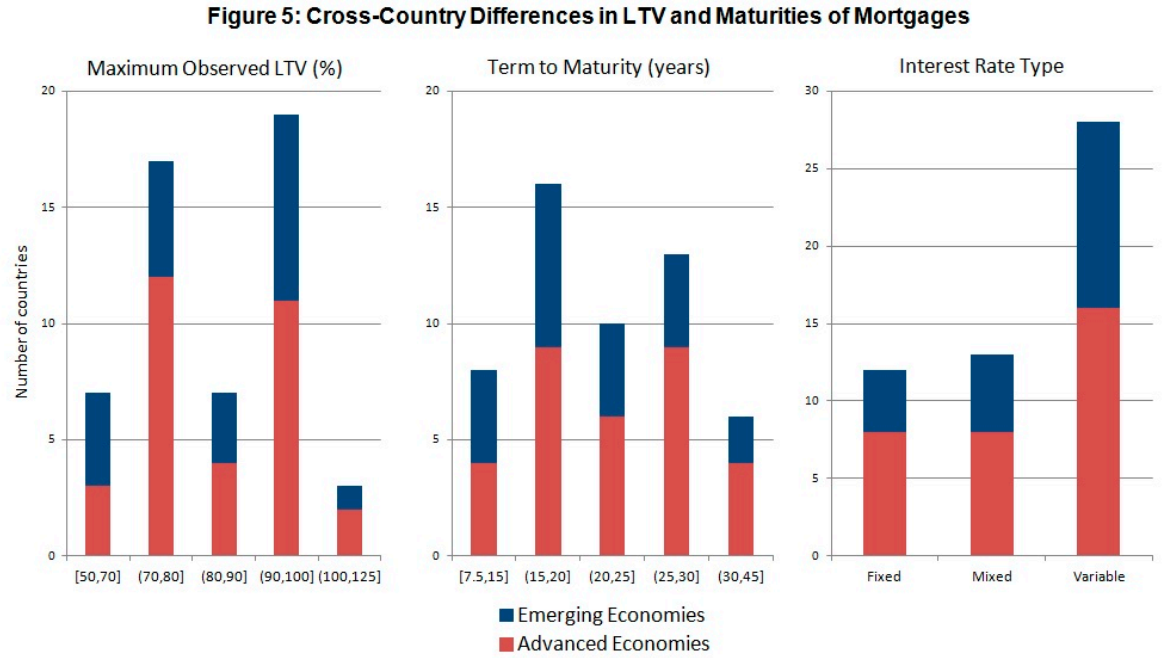

Interest Type: Mortgage rates can be fixed through the life of a loan, or vary over time with changes linked to key interest rates in the economy. In our sample, the standard mortgage rate is variable in 30 countries, fixed in 12 countries; while in the remaining 14 countries both contracts are observed. Variable rates are more common in emerging economies (Figure 5).

Funding Model: There is also heterogeneity across countries' funding models (for example, retail deposits, covered bonds, securitization) used for financing mortgages. Moreover, different funding models can be present simultaneously within the same country. In this context, we differentiate between countries that use retail deposits as the primary source of financing and others that rely more on alternative funding sources. In most of our sample (44 countries), banks funded mostly by retail deposits play a major role in mortgage lending (Figure 6). ${ }^{5}$

Degree of Lender Recourse on Mortgages: The rights of lenders to pursue a borrower's assets (other than the house securing the mortgage) in case of a default, referred to as the right to recourse, also varies across countries (and sometimes, across jurisdictions within the same country, such as across different states in the United States). In about 44 of the 53 countries in the sample, there is full recourse on mortgages. Full recourse increases borrowers' incentives to

\footnotetext{
${ }^{5}$ This is the case in most emerging markets but also in some advanced economies, such as Canada, France, and Germany. The role of nonbanks and the use of wholesale and cross-border funds is important in about 22 countries. These include the United States (securitization), Sweden, and Denmark (covered bonds), and Australia and South Africa (wholesale funding).
} 
honor the terms of the contract and has been associated with lower default rates (see DuyganBump and Grant, 2008, for evidence from Europe).

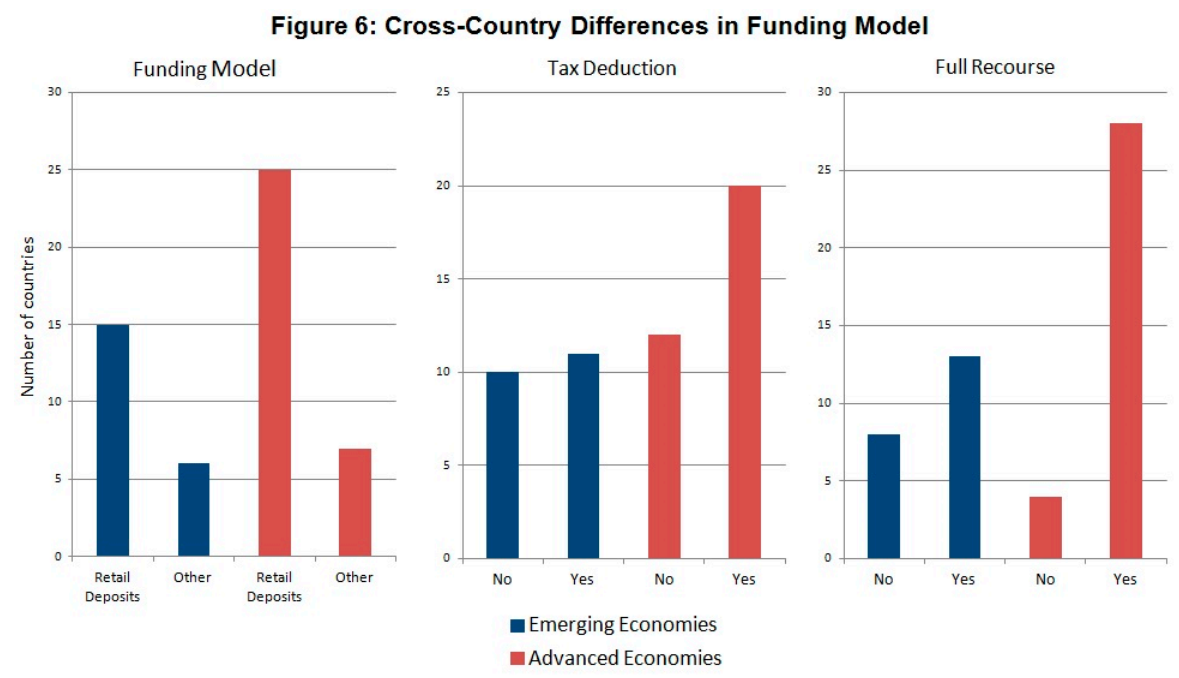

Mortgage Interest Tax Deduction: In 33 of the countries in our sample, households are allowed to deduct mortgage interest payments from their taxable income. Interest deductibility is more common in advanced economies than in emerging market countries (about two-thirds versus half of the cases in our sample; Figure 6). And it varies substantially from country to country. In many cases, deductions are capped to a maximum (for example, Poland and South Korea), and the United States and Norway are the only cases that allow for nearly full deductibility without taxing imputed rents (IMF, 2011). Government support to mortgage markets can go beyond interest rate deductibility, and include subsidies (for example, first-time buyers or other selected groups), a government agency providing guarantees and/or loans, capital-gain tax deductibility, and state-owned institutions playing a major role in the mortgage market (IMF, 2011). But cross-country data availability limits our focus to interest deductibility.

Following and augmenting the current literature on the importance of institutional and macroeconomic factors, we analyze the correlation of the average mortgage depth over 200005, measured as the ratio of total mortgage debt to GDP, with institutional, macroeconomic, and house financing characteristics (See Annex II for further details). Although the cross-sectional nature of the data makes it difficult to attribute a definitive causal interpretation, similar to Warnock and Warnock (2012), we find that institutional factors, such as the strength of legal rights and ease of registering property, are statistically significantly correlated with the size of mortgage markets (see the cross-country differences in Box 1). The analysis also highlights a positive relationship with per-capita GDP, which is also a good proxy for hard-to-measure differences in institutional quality and in the level of financial development. More interestingly in our context, housing finance characteristics - LTV, term-to-maturity, and funding modelalso contribute to explaining part of the cross-country variation in the depth of mortgage markets relative to a specification based solely on macro and institutional variables. However, the fit of the model improves by only about 10 percent when adding house finance characteristics on top of the institutional (for example, ease of registering property) and GDP per capita, which remain statistically significant. 


\section{HOUSING FINANCE AND REAL-ESTATE BOOMS}

There are several reasons why real-estate and mortgage markets sit at the nexus of macroeconomic and financial stability. First, size matters. As seen in the previous section, realestate-related lending accounts for a large share of household credit and often a major portion of a financial sector's activities. Second, leverage matters. Through mortgages, households are allowed leverage limits much higher than with other asset classes. Further, real estate is collateral for not only households and construction companies, but also firms in other sectors. And major mortgage lenders are typically commercial banks, which are themselves leveraged. In this context, mortgage markets might become excessively large or increase swiftly due to lax lending standards or distorted incentives (for example, implicit leverage subsidies linked to interest deductibility) harboring vulnerabilities for the overall economy.

This section explores the relationship between mortgage credit, house-price dynamics, and realsector performance; and the extent to which it is influenced by housing finance characteristics. Since long time-series on mortgage credit are lacking in many countries, we rely instead on household credit. Mortgage debt typically represents a large share of household debt (the median mortgage-to-household credit ratio is about 70 percent in our sample), and the two variables are highly correlated. ${ }^{6}$ This finding suggests that approximating mortgage credit with household credit is appropriate given the data constraints. ${ }^{7}$

\section{A. Defining and Identifying Credit Booms and Real-Estate Booms}

There is no widely accepted definition of what constitutes a real-estate or a credit boom. These episodes are generally defined as large and persistent deviations of these variables from some historical norm. And previous literature has employed different definitions of historical norm (different filters, different time windows, country-specific or not) and different approaches to measure these deviations (different thresholds, real versus nominal growth, absolute levels and values relative to GDP). ${ }^{8}$

Here we focus on the real growth of both house prices and credit and define boom episodes as deviations from a country-specific historical norm. Specifically, we identify episodes by

\footnotetext{
${ }^{6}$ The correlation ranges from 0.46 to 0.99 , with a median of 0.99 and only six countries with a correlation below 0.9

${ }^{7}$ Unfortunately, household credit does not include nonbank lending which can be significant in some countries, such as the United States, but is usually correlated with bank lending (see, for example, Dagher and Fu, 2011).

${ }^{8}$ For credit booms, most studies compare a country's credit-to-GDP ratio to its nonlinear trends (Gourinchas, Valdes, and Landerretche, 2001; Mendoza and Terrones, 2008, Dell'Ariccia and others, 2012). However, for housing booms, the focus is usually on variations in real house prices (Agnello and Schuknecht, 2011).
} 
comparing the real evolution (measured at year-over-year rates) of credit and house prices at quarterly frequency. We classify an episode as a boom if the following two conditions are

\section{Box 1: Cross-Country Institutional Differences Related to Housing Markets}

There is substantial heterogeneity in terms of countries' institutional factors. The legal-right index from the World Bank's Doing Business reports (WBDB), which is a proxy of the extent to which the country's bankruptcy and collateral laws facilitate lending, shows that most emerging economies and a few advanced economies in our sample display relatively low legal-right indexes (chart, top left-hand-side panel). The ease-of-registering property index also shows high heterogeneity across countries (bottom panel). Finally, cross-country differences are not as sharp with regard to the WBDB credit-information index, which measures lenders' access to standardized and informative sources of borrowers' history and creditworthiness.
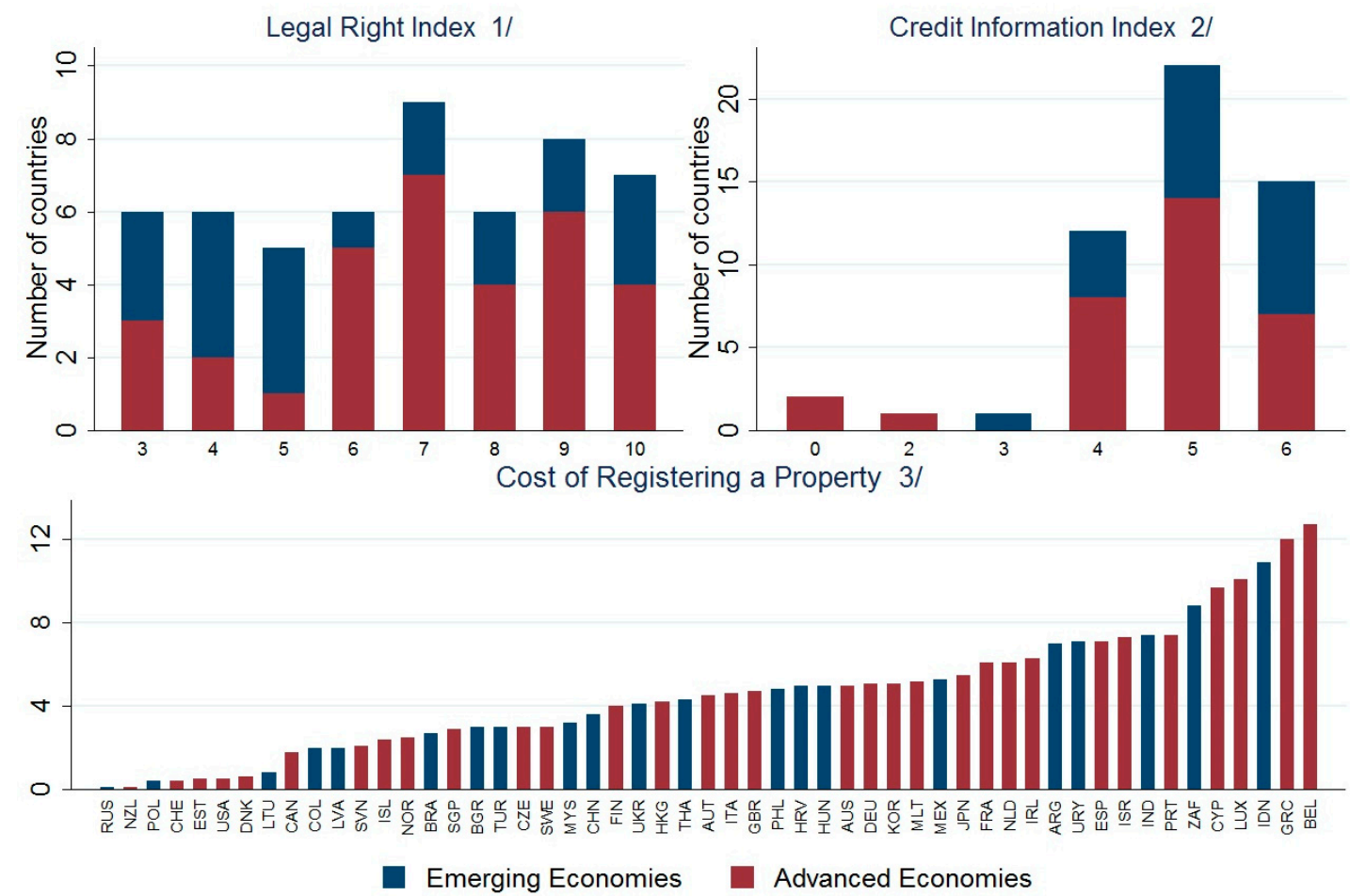

Source: World Bank, Doing Business, 2005 data.

$1 /$ It measures the extent to which the country's bankruptcy and collateral laws facilitate lending.

$2 /$ It measures the depth of lenders' access to standardized and informative sources of credit information on potential borrowers.

3/ It measures the costs of registering a property.

satisfied: (i) the real growth rate of credit (house prices) is greater than 10 (5) percent, or two standard deviations of the country-specific distribution of credit (house prices) real growth rates in a given quarter; and (ii) the real growth rate of credit (house prices) is above 10 (5) percent or one standard deviation of the country-specific distribution of credit (house prices) real growth rates for a period of at least two years. The first condition ensures that a boom episode contains 
at least a quarter with an annual growth rate above 10 percent or two standard deviations for credit, and above 5 percent or two standard deviations in the case of house prices. The second conditions rules out very short-lived spikes in credit and house prices. ${ }^{9}$

\section{Occurrence of credit booms}

We apply this definition to the 53 countries for which house-price, household-credit, and corporate-credit data are available on a quarterly basis. The sample starts as far back as the 1970s, for some countries, and extends to 2012. We focus our attention on three different types of credit booms: (i) household-credit booms; (ii) corporate-credit booms; and (iii) overall private-sector-credit booms. Although private credit is the sum of household and corporate credit, we include it separately in the analysis. First, it is a useful benchmark as the variable most often used in previous studies on credit booms. Second, private-credit booms generally coincide with generalized credit overheating episodes in which both household and corporate credit are booming.

Based on our definition, we find 83 household-credit booms, 68 corporate-credit booms, and 67 private-credit booms during the period 1970-2012. Reflecting the composition of our sample, most episodes (about 60 to 65 percent) occur in advanced countries. However, once we control for this bias, emerging markets appear to be in a boom state more often than advanced economies (the portion of quarterly observations classified as booms is roughly double that of advanced economies).

The higher frequency of household-credit booms is reflected in Figure 7, which shows the proportion of countries that are experiencing credit booms during each quarter. ${ }^{10}$ The higher occurrence of credit booms after the 1980s could be at least partly attributed to the wave of banking and mortgage deregulation as well as to financial innovations such as the rise in securitization (for more details see IMF, 2008, and Muellbauer and Murphy, 1997). The picture also suggests that booms tend to come in bunches, suggesting that global factors play at least some role (Mendoza and Terrones, 2008).

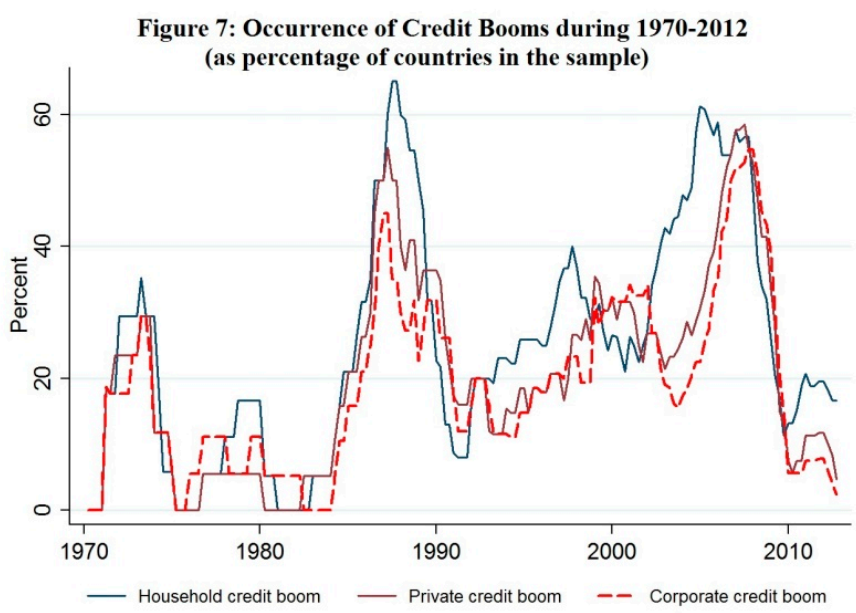

\footnotetext{
${ }^{9}$ As shown in Annex III, our results are robust to changing the ad hoc thresholds to the upper quarter of the distributions and reducing the minimum duration of booms to six quarters.

${ }^{10}$ Although the overall peaks on the incidence of household-credit booms seems to precede other credit booms since the mid-1990s, this pattern is not uniform within individual countries. There are 17 cases of household-credit booms preceding house prices booms, and 10 cases in which the opposite took place.
} 


\section{Occurrence of house-price booms}

We identify 85 house-price booms ${ }^{11}$ Most countries in the sample experienced at least one of these episodes. And, as shown in Figure 8 , the all-time peak in the relative occurrence of house-price booms was during the period just before the recent global financial crisis (in 2005, there were booms in more than half of the sampled countries). Not surprisingly, booms were rare in the immediate aftermath of the global financial crisis: less than 10 percent of the countries were experiencing a credit boom as of 2012:Q4. ${ }^{12}$

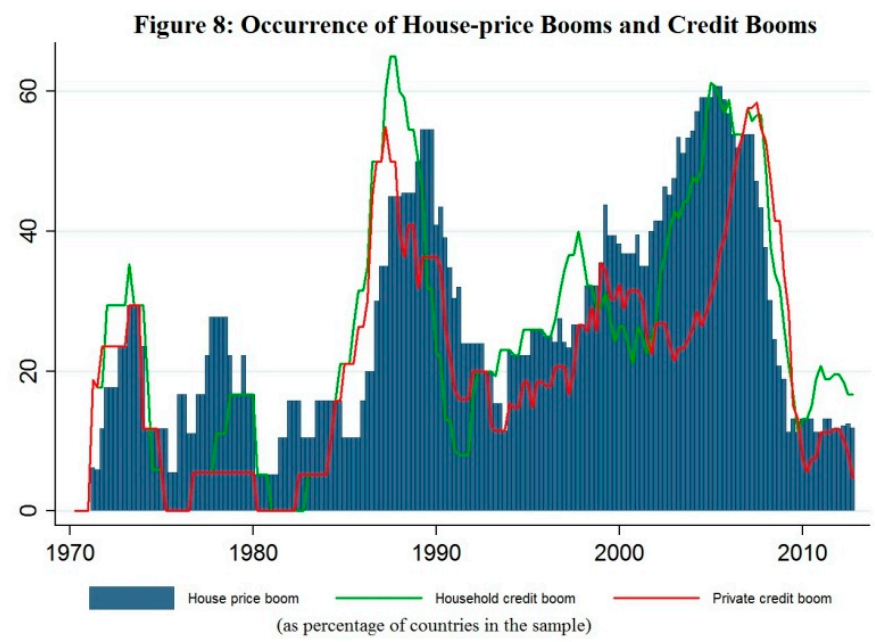

Household-credit booms and house-price booms tend to occur together. Moreover, they seem more in sync than private-credit booms and house-price booms. This aligns with findings that household credit is a better proxy for understanding house-price fluctuations than the commonly used private-sector credit. $^{13}$

\section{B. Interaction between Real-Estate Booms and Credit Booms}

The rest of this section explores the historical relationship between credit booms and houseprice booms and the macroeconomic performance around these episodes. Then, it studies the factors that can help predict whether house-price booms will turn into recessions and/or financial crises.

\section{Can credit booms help predict house-price booms?}

Regression analysis suggests that household-credit booms are good predictors of real-estate booms (see Annex IV). The presence of a household-credit boom increases the probability of a

\footnotetext{
${ }^{11}$ See Annex I for data sources on house prices. While in some countries, particularly some Organisation for Economic Co-operation and Development (OECD) countries, several indices are available to measure house prices, addressing differences between these indices is beyond the score of this cross-sectional study. We rely on publicly available data from OECD instead.

${ }^{12}$ These countries were Brazil, Hong Kong, India, Israel, Malaysia, and Norway.

${ }^{13}$ Following the literature, we also regress the yearly change in house prices (using quarterly data) on lag changes in house prices, credit, employment, and the level of interest rates. We find that household-credit growth is a strong predictor of house-price growth. A 1 percent increase in household credit is associated with about 0.2 percent increase in house prices in the following year. We compare private credit with household credit and find that the latter is a much stronger and more robust predictor of house-price growth.
} 
real-estate boom to 57 percent from an unconditional probability of 29 percent. Across specifications, household-credit booms are better predictors of house-price booms than privatecredit booms. In contrast, the level of household debt to GDP (a proxy for household leverage) is negatively correlated with the occurrence of real-estate booms. Global factors simultaneously driving house-price booms across countries are captured by the evolution of the Federal Funds rates and Chicago Board Options Exchange Market Volatility Index (VIX). Lagged GDP growth is positively associated with the probability of a real-estate boom, suggesting that these booms tend to start during or after buoyant economic growth.

With respect to housing finance characteristics, the analysis indicates that the higher the maximum observed LTV, the higher the probability of a real-estate boom. This most likely captures the effect of relaxed lending standards on house prices, and is supported by other studies (Crowe and others, 2011; IMF, 2011; and Cerutti, Claessens, and Laeven, 2015) that have found a positive relationship between LTV limits and houseprice increases over time. Hence, to the extent that this coefficient can be given a causal interpretation, LTVs appear to be a well-targeted tool for limiting real-estate price fluctuations.

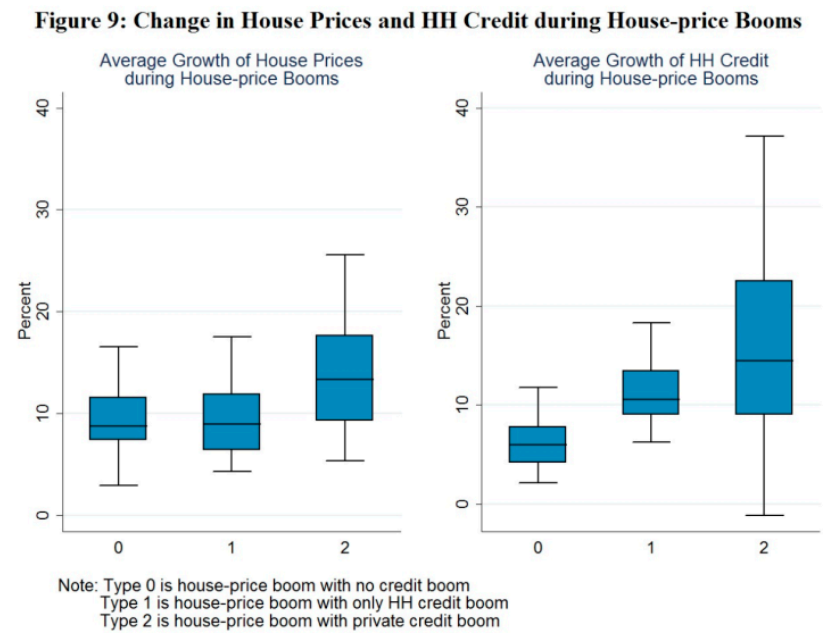

\section{Classifying real-estate booms based on the evolution of credit}

So far the analysis has highlighted that credit booms, especially household-credit ones, are good predictors of real-estate booms. In the rest of the section, we further explore this interaction by identifying the characteristics and consequences of real-estate booms as a function of whether they coincided with: (i) no credit booms; (ii) only corporate-credit booms, (ii) only householdcredit booms, and (iv) private (twin household and corporate) credit booms.

Table 1: Characteristics of House-price Booms

\begin{tabular}{|c|c|c|c|c|c|c|c|c|c|c|c|}
\hline \multirow[t]{2}{*}{ Boom Classification } & \multirow[t]{2}{*}{$\begin{array}{l}\text { Number of } \\
\text { episodes }\end{array}$} & \multicolumn{2}{|c|}{ Duration } & \multicolumn{2}{|c|}{$\begin{array}{c}\text { Average growth of } \\
\text { house price }\end{array}$} & \multicolumn{2}{|c|}{$\begin{array}{c}\text { Average growth of } \\
\text { household credit }\end{array}$} & \multicolumn{2}{|c|}{$\begin{array}{l}\text { Average growth of } \\
\text { firm credit }\end{array}$} & \multicolumn{2}{|c|}{$\begin{array}{c}\text { Average growth of } \\
\text { private credit }\end{array}$} \\
\hline & & Mean & Median & Mean & Median & Mean & Median & Mean & Median & Mean & Median \\
\hline $\begin{array}{l}\text { House-price booms without } \\
\text { any credit boom }\end{array}$ & 18 & 13.6 & 10.5 & 10.1 & 8.7 & 4.7 & 5.9 & 4.8 & 5.4 & 5.2 & 5.3 \\
\hline $\begin{array}{l}\text { House-price booms with only } \\
\text { household credit boom }\end{array}$ & 16 & 13.9 & 13.0 & 9.4 & 9.0 & 11.2 & 10.5 & 2.8 & 3.8 & 5.6 & 6.3 \\
\hline $\begin{array}{l}\text { House-price booms with } \\
\text { private credit boom }\end{array}$ & 49 & 18.3 & 15.0 & 14.8 & 13.3 & 20.0 & 14.5 & 12.9 & 11.2 & 14.8 & 13.1 \\
\hline $\begin{array}{c}\text { No house-price boom } \\
\text { episodes }\end{array}$ & - & - & - & -1.7 & -1.1 & 5.2 & 4.3 & 3.8 & 3.2 & 4.3 & 3.5 \\
\hline
\end{tabular}

Source: IMF staff estimations based on Bank for International Settlements; central bank data; Haver Analytics; and IMF, International Financial Statistics.

Notes: A total of 85 house-price booms were identified. In addition of the 83 house-price booms presented in the table, there are two house-price booms which were associated with corporate credit booms (Hong Kong 2004:Q1-05:Q4 and Singapore 2006:Q3-08:Q2). They are not reflected in the table because their small sample does not provide enough observations for meaningful comparisons with the other type of house-price booms. 
Most real-estate booms in the sample coincide with private (twin household and corporate) credit booms. ${ }^{14}$ Table 1 shows that 49 of the 85 real-estate booms coincide with private-credit booms. There are 16 real-estate booms accompanied by household-credit (but not aggregate) booms. And only two house-price booms in the sample are associated with booms limited to corporate credit (Hong Kong 2004:Q1-05:Q4 and Singapore 2006:Q3-08:Q2). While they may make for interesting case studies, these findings are too few in number for meaningful comparison with the other type of house-price booms. Finally, 18 real-estate booms happened without any type of credit booms. ${ }^{15}$

Real-estate booms associated with different types of credit episodes also differ with regard to size and duration. On average, house-price booms accompanied by private-credit booms (about 18 quarters) last longer than the other two cases (about 14 quarters). The average real increase in house prices during booms accompanied by a private-credit boom (14 percent) is higher than in episodes with only household-credit booms ( 9 percent) and without any credit boom (10 percent). Similarly, as also shown in Figure 9, the average real household-credit growth is much larger in the case of house-price booms accompanied by private (twin householdcorporate) credit booms (about 21 percent) than in the case of house-price booms with only household-credit booms (11 percent) or without any credit booms (5 percent).

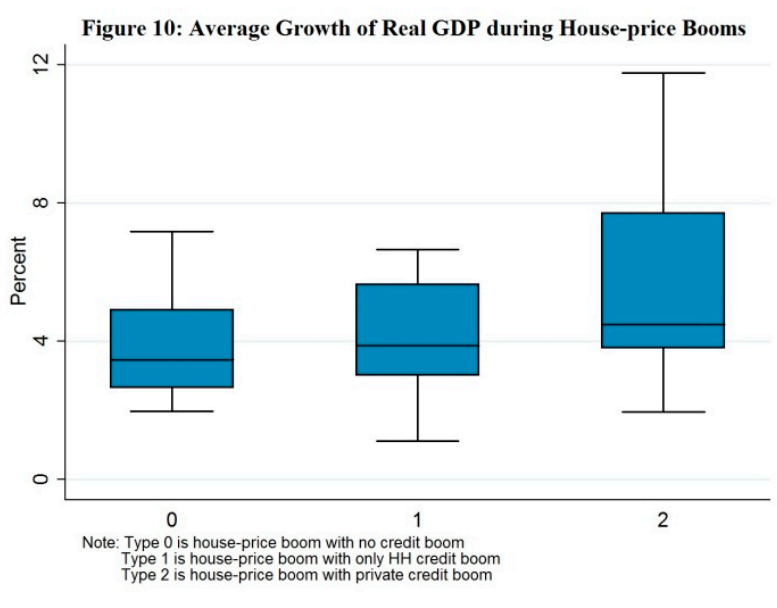

\section{Macroeconomic performance during real-estate booms}

As discussed previously, real economic activity, aggregate credit, and house-price fluctuation are closely linked through wealth effects and the financial accelerator mechanism (see, among others, Bernanke and Gertler, 1989; Kiyotaki and Moore, 1997; Gilchrist and Zakrajsek, 2008, Mian and Sufi, 2011, Quint and Rabanal, 2014). In an upturn, better growth prospects improve borrower creditworthiness and collateral values. Lenders respond with an increased supply of credit and, sometimes, looser lending standards. More abundant credit allows for greater

\footnotetext{
${ }^{14}$ In the presence of a housing boom, a private-credit boom episode coincides almost always with simultaneous household and corporate credit booms. There are only four exceptions, when the very high growth in household credit growth triggered a private-credit boom without the presence of a corporate credit growth. These cases are Canada 1973:Q1-76:Q1, Czech Republic 2006:Q3-08:Q4, Denmark 2004:Q1-07:Q1, and Greece 2005-07:Q1.

${ }^{15}$ Many of these episodes may have been driven by country-idiosyncratic shocks and/or structural characteristics. For example, Germany's boom during 1990:Q1-92:Q2 was supported by post-reunification fiscal measurestemporary generous tax breaks for remodeling or building real estate in the former East Germany or Berlin. The house-price booms in Canada during the period 2002:Q2-08:Q2 reflected some regional economic booms, together with a conservative residential mortgage market in terms of regulation, and with lack of some fiscal incentives such as tax deductibility of mortgage interests (see IMF, 2009). There are also about six house-price booms during which there was a simultaneous spike in credit, but it was not persistent enough to satisfy our credit-boom criteria.
} 
investment and consumption and further increases house prices and collateral values. In a downturn, the process is reversed.

In this context, not surprisingly, economic activity is significantly higher during real-estate booms compared to non-boom years (See Table 2 and Figure 10). Real GDP growth during housing booms is higher than during non-boom periods by about $1 \frac{1}{4}$ to $2 \frac{1}{2}$ percent. These differences are statistically significant (see $p$-values in the lower part of Table 2). In addition, the different performances among housing boom types shows that housing booms that coincide with private-credit booms register higher (statistically significant) real-GDP growth than episodes accompanied by household-credit booms or occurring in the absence of a credit boom.

Consistently, consumption and investment growth are higher during house-price booms with private-credit booms than in tranquil times (see $p$-values of joint coefficient test for "Type 2 and 3 are the same" in Table 2). There is also evidence of an appreciation of the exchange rate with housing booms that were accompanied by credit booms. This is consistent with the literature (for example, Dell'Ariccia and others, 2012) that highlights that credit booms are associated with real exchange-rate appreciations and current-account deteriorations.

\begin{tabular}{|c|c|c|c|c|c|c|c|c|}
\hline \multirow[b]{2}{*}{ Boom Classification } & \multirow[b]{2}{*}{ Type } & \multirow[b]{2}{*}{$\begin{array}{c}\text { Number of } \\
\text { Observations }\end{array}$} & \multicolumn{6}{|c|}{ Macro performance during the boom } \\
\hline & & & $\begin{array}{l}\text { Average } \\
\text { RGDP } \\
\text { growth }\end{array}$ & $\begin{array}{l}\text { Average } \\
\text { Inflation }\end{array}$ & $\begin{array}{c}\text { Average } \\
\text { change of } \\
\text { Exchange } \\
\text { rate }(\mathrm{NC} / \$)\end{array}$ & $\begin{array}{c}\text { Average } \\
\text { Consumption } \\
\text { growth }\end{array}$ & $\begin{array}{c}\text { Average } \\
\text { Investment } \\
\text { growth }\end{array}$ & $\begin{array}{c}\text { Average } \\
\text { Current } \\
\text { account } \\
\text { (percent of } \\
\text { GDP) }\end{array}$ \\
\hline $\begin{array}{l}\text { House-price booms without } \\
\text { any credit boom }\end{array}$ & 0 & 18 & 3.95 & 5.95 & 0.22 & 3.65 & 4.51 & 1.01 \\
\hline $\begin{array}{l}\text { House-price booms with } \\
\text { only household credit boom }\end{array}$ & 1 & 16 & 4.06 & 3.69 & -4.10 & 1.02 & 1.74 & -0.81 \\
\hline $\begin{array}{l}\text { House-price boom with } \\
\text { private credit boom }\end{array}$ & 2 & 49 & 5.84 & 5.08 & -1.30 & 2.26 & 5.00 & -1.88 \\
\hline Non boom episodes & 3 & - & 2.67 & 5.23 & 2.02 & 1.31 & 1.19 & 0.01 \\
\hline \multicolumn{3}{|c|}{ Joint coefficients tests } & \multicolumn{6}{|c|}{ ( $p$ values) } \\
\hline & \multicolumn{2}{|c|}{ Type 0 and 3 are the same } & 0.03 & 0.56 & 0.27 & 0.07 & 0.08 & 0.39 \\
\hline & \multicolumn{2}{|c|}{ Type 1 and 3 are the same } & 0.01 & 0.03 & 0.00 & 0.25 & 0.05 & 0.45 \\
\hline & \multicolumn{2}{|c|}{ Type 2 and 3 are the same } & 0.00 & 0.74 & 0.00 & 0.02 & 0.00 & 0.06 \\
\hline & \multicolumn{2}{|c|}{ Type 0 and 1 are the same } & 0.87 & 0.12 & 0.02 & 0.05 & 0.14 & 0.25 \\
\hline & \multicolumn{2}{|c|}{ Type 0 and 2 are the same } & 0.04 & 0.41 & 0.39 & 0.16 & 0.77 & 0.10 \\
\hline & \multicolumn{2}{|c|}{ Type 1 and 2 are the same } & 0.05 & 0.12 & 0.09 & 0.08 & 0.02 & 0.56 \\
\hline
\end{tabular}

Source: IMF staff estimations based on Bank for International Settlements; central bank data; Haver Analytics; and IMF, International Financial Statistics

Notes: A total of 85 house-price booms were identified. In addition of the 83 house-price booms presented in the table, there are two houseprice booms which were associated with corporate credit booms (Hong Kong 2004:Q1-05:Q4 and Singapore 2006:Q3-08:Q2). They are not reflected in the table because their small sample does not provide enough observations for meaningful comparisons with the other type of house-price booms.

Finally, the analysis shows that inflation typically remains subdued and is not much different from levels that prevail in tranquil times. This is in line with the recent empirical evidence documenting how credit and asset-price imbalances can grow under seemingly tranquil macroeconomic conditions (low and stable inflation and output gap). It suggests that, should 
monetary policy lean against the wind to contain these kind of episodes, a tradeoff might emerge (at least in the short-run) with its traditional price-stability objective. (See Bayoumi et al., 2014, for a review of the debate on the role of monetary policy in containing asset-price booms.)

\section{Performance in the aftermath of real-estate booms}

House prices generally decline after real-estate booms (although not in all cases), and in several cases, the adjustment is substantial. Figure 11 (left-hand side) displays the correction in house prices observed within a three-year window after the end of real-estate booms. Real-estate booms that occur with private-credit booms (type 2 in the figure) tend to be followed by the largest falls in house prices. Further, there is little evidence that these sharp declines are systematically followed by rebounds (Figure 11, right panel).
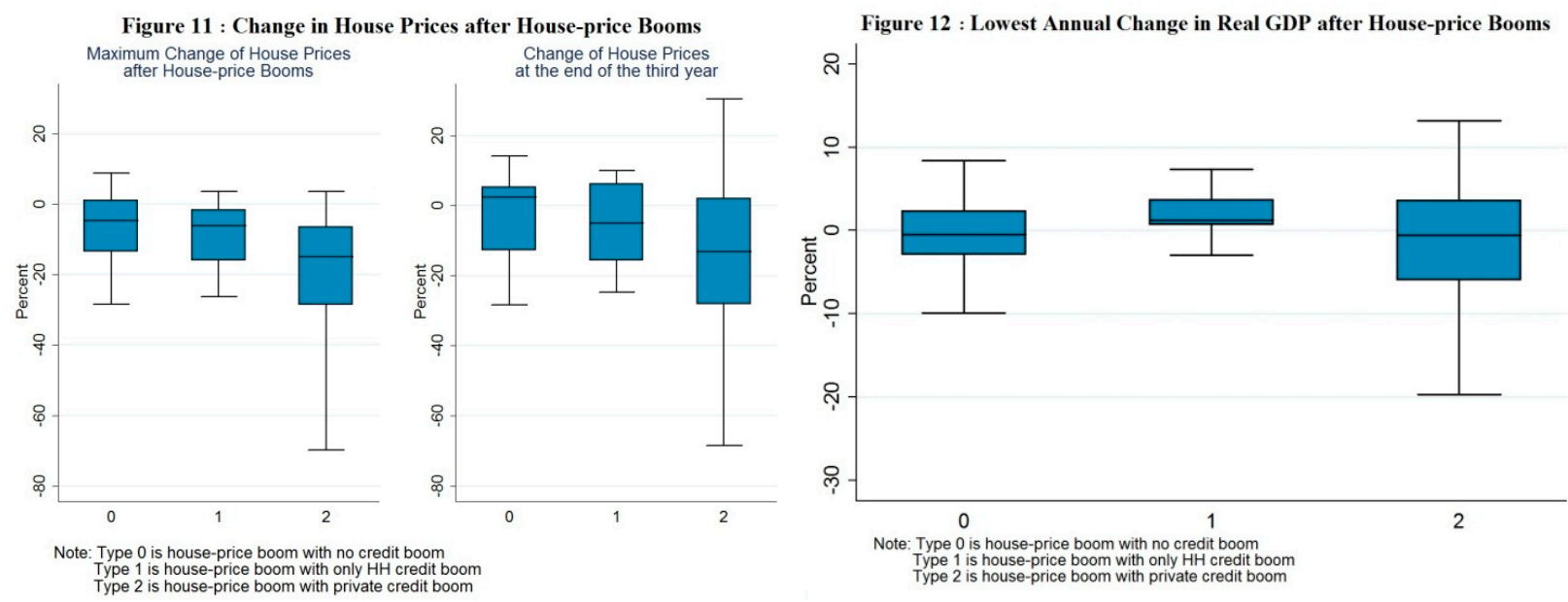

Drops in house prices are generally accompanied by recessions (in our sample, 49 out of 78 house-price booms ended up in recessions). ${ }^{16}$ Yet, there is substantial heterogeneity in the performance of real GDP post real-estate booms (see Figure 12). This largely depends on whether a bust occurs. Indeed, output losses in recessions accompanied by housing busts are two to three times greater than in "normal" recessions (Claessens, Kose, and Terrones, 2008).

\section{Can we tell bad real-estate booms from good ones?}

The previous analysis has shown that the end of a real-estate boom is often related to significant falls in house prices and economic recessions. The question then arises whether these "bad" booms can be distinguished from "good" ones (those that do not end up in recessions) ahead of time. We address this question by exploring whether a boom's characteristics, such as duration,

\footnotetext{
${ }^{16}$ Although we have identified 85 real-estate booms, there are seven cases for which insufficient time (three years) has passed since the end to be able to determine whether a recession was present. The end of a housing boom is followed by a recession if the real GDP growth (year-over-year) of two or more consecutive quarters is negative within a three-year interval after the end of the boom.
} 
associated type of credit boom, and housing finance characteristics, can help predict whether it will lead to a recession. ${ }^{17}$

Figure 13: Good and Bad Booms
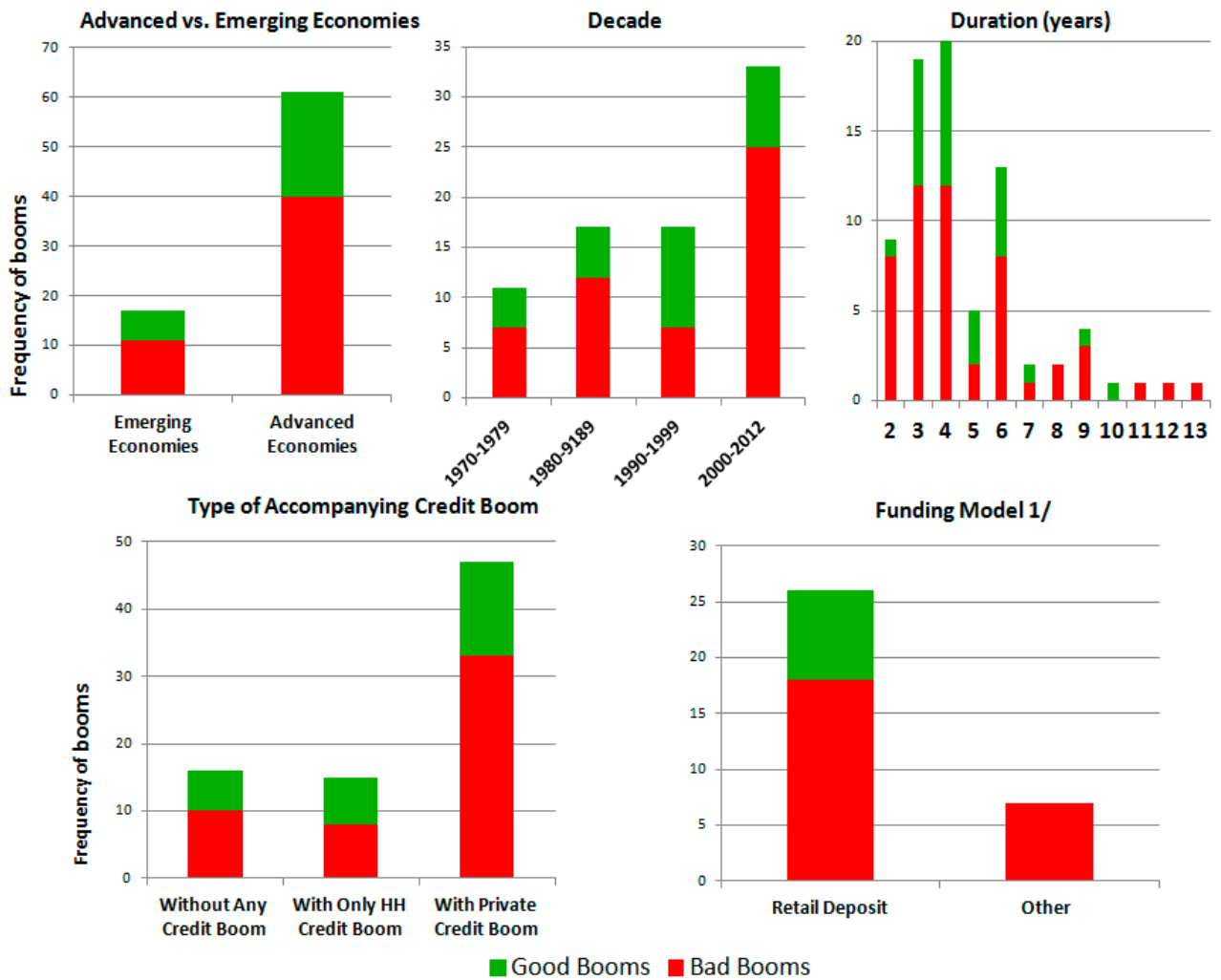

Note: The total number of booms that can be identified as good or bad is 78 .

$1 / 33$ house price boom episodes (out of 78) are shown since funding model characteristics are availabe only since 2000.

About two-thirds of the booms in our sample end badly according to the above criteria. And this proportion is about the same in advanced economies and emerging markets (Figure 13). The timing of the booms shows that not only did more booms occur since 2000 , but also that a much larger proportion ended in recessions. The role of the 2007-09 global financial crisis is evident in the right-hand-side panel of Figure 13. There does not seem to be a clear relationship between a boom's duration and the probability that it will end up badly.

The type of credit boom accompanying a real-estate boom sheds some light on how it could end (Figure 13). Real-estate booms accompanied by private-credit booms (twin household-corporate

\footnotetext{
${ }^{17}$ Following the credit boom literature (for example, Dell'Ariccia and others, 2012) we also computed how many housing boom were followed by a banking crisis within the three-year period after the end of the boom. In our sample, about one in five housing booms (about 13 cases) are followed by a systemic banking crisis. However, this analysis is not reported because we did not find any clear link between a house-price boom ending in a systemic banking crisis and our set of underlying house-price boom characteristics. This finding is in line with Drehmann and Juselius (2013) who do not find house price growth as a good predictor of systemic banking crisis.
} 
credit) are more likely to end in recessions than housing booms accompanied by only household-credit booms or without any credit booms. The funding model of housing finance also seems to matter. In countries that finance housing credit primarily through bank retail deposits, booms have a lower probability of ending in recessions. Perhaps this reflects the fact that access to wholesale markets generally increases the leverage of mortgage lenders, increasing the potential sharp deterioration of lenders' balance sheets in a bust (as during the global financial crisis). ${ }^{18}$ A more formal analysis summarized in Annex V confirms these findings, for the period after 2000 when house finance characteristics are available.

\section{POLICY IMPLICATIONS}

The recent global financial crisis has placed the housing market at the center stage of economic policy discussions on financial stability. While the advantages of a deep mortgage market cannot be ignored, it is now also widely recognized that housing credit excesses happen and that their far-reaching negative consequences warrant a reassessment of how macroeconomic policy should look at real-estate market developments. Against this background, we analyzed how mortgage-market depth varies across countries, and the dynamic relationship between housing finance and house-price and credit boom-bust episodes.

The findings in this note indicate that cross-country differences in the depth of mortgage markets are associated with institutional elements (for example, collateral and bankruptcy laws that define the legal rights of borrowers and lenders, and the ease of registering property), macroeconomic factors (for example GDP per capita), and some housing finance characteristics. These differences suggest that there is room for policy action. As suggested in the literature (for example, Warnock and Warnock, 2012), several emerging and advanced countries could improve access to house financing through better legal frameworks and more stable macroeconomic environments. Deeper and more inclusive (for example with low down-payment ratios) mortgage markets are correlated with higher home ownership. And higher home ownership rates are linked to social benefits, such as higher school attainment, higher social capital, lower crime, and higher levels of life satisfaction and psychological health.

\footnotetext{
${ }^{18}$ There are three factors that could potentially contribute to this relation between the funding of mortgages and the outcome of the boom. First, as shown in Hahm, Shin, and, Shin (2011), episodes of rapid increases in leverage are typically financed through wholesale funding. Second, wholesale funding exposes banks to liquidity shocks resulting in sharper contraction in credit during crises (see for example, Cornett, McNutt, and Strahan, 2011; Dagher and Kazimov, 2012). Third, to varying degrees across countries, some of the non-retail lending is channeled through less regulated nonbank entities. These finance companies have been shown to have contributed disproportionally to the deterioration in lending standards during the U.S. mortgage boom (see Dagher and Fu, 2011).
} 
However, some of the housing finance characteristics that favor mortgage market deepening, by increasing access and affordability, may also promote fast credit growth and eventually entail greater risks to financial stability. Relaxed lending standards, such as higher LVRs and longer maturity of mortgages, seem to correlate with "excessively" rapid house credit growth and costly boom-bust cycles. We also find that house-price booms that are funded through wholesale markets are more likely to end badly (that is, in recessions).

In this context, housing finance regulation - which is nowadays a widely accepted part of the macroprudential policy arsenal — could play a role in reducing the frequency and severity of housing boom episodes. Unlike monetary policy that requires an overall increase in interest rates to dampen household/mortgage credit, if effective, macroprudential policies could target directly household leverage and indebtedness and the risk profile of mortgage originators and investors (Dell' Ariccia and others, 2012).

While these findings confirm previous work identifying macroprudential policies as useful tools for containing systemic vulnerabilities, our historical analysis also highlights that the role of monetary policy should not be downplayed. About 60 percent of the real-estate booms in our sample occurred together with private-credit booms. Moreover, in those episodes, the occurrence of a private-credit boom was not only associated with simultaneous household- and corporate-credit booms, but also with rapid and broad economic growth. These signs of overheating in other sectors could call for monetary policy tightening (Crowe and others, 2011; Dell'Ariccia and others, 2012; IMF, 2013b) after weighing the potential benefits and risks to financial stability. Monetary policy tightening could have both positive and negative effects on financial stability, and these need to be weighed before resorting to such policy during a boom. On the risks side, monetary policy can weaken financial conditions of households and firms, increase the interest rate burden, induce deleveraging and reduce the value of legacy assets. However, by reducing the leverage (or the rate of increase in leverage) monetary policy can strengthen financial stability over the medium term. However, the absence of inflation pressure during many real-estate booms calls for close consideration of proposals in favor of including real-estate prices in monetary policy response functions (Iacoviello, 2005; Aspachs-Bracons and Rabanal, 2011)

Finally, dealing with real-estate booms effectively requires a broad mix of policies that goes beyond the use of macroprudential and monetary policies, and may also involve realignment of incentives over the long run. Well-paced country-specific measures to strengthen supply-side responses would mitigate the impact of demand shocks over the long run. Abrupt supply-side modification at the peak of house-price booms or at the beginning of house-price busts could exacerbate the correction in house prices. More generally, the policy mix should also include measures to minimize distortions linked to special treatment of housing and homeownership. 


\section{References}

Aaronson, D., 2000, “A Note on the Benefits of Homeownership," Journal of Urban Economics, Vol. 47, No. 3, pp. 356-36.

Agnello, L., and L. Schuknecht, 2011, "Booms and Busts in Housing Markets: Determinants and Implications," Journal of Housing Economics, Vol. 20, No. 3, pp. 171-90.

Andrews, D., and A. Sanchez, 2011, "Drivers of Homeownership Rates in Selected OECD Countries," OECD Economics Department Working Papers No. 849, Organisation for Economic Co-operation and Development, Paris.

Anundsen, A. K., and C. Heeboll, 2013, "Supply Restrictions, Subprime Lending and Regional US Housing Prices," Memorandum 04, Department of Economics, University of Oslo, Olso.

Aspachs-Bracons, O., and P. Rabanal, 2011, "The Effects of Housing Prices and Monetary Policy in a Currency Union," International Journal of Central Banking, International Journal of Central Banking, Vol. 7, No. 1, pp. 225-74.

Bayoumi, T., G. Dell'Ariccia, K. Habermeier, T. Mancini, F. Valencia, and IMF staff team, 2014, "Monetary Policy in the New Normal," IMF Staff Discussion Note 14/03, International Monetary Fund, Washington.

Beck, T., and R. Levine, 2008, "Legal Institutions and Financial Development," In Handbook of New Institutional Economics, C. Menard and M. M. Shirley eds., pp. 251-78.

Bernanke, B., and M. Gertler, 1989, “Agency Costs, Net Worth, and Business Fluctuations," American Economic Review, Vol. 79, No. 1, pp. 14-31.

Bicakova, A., and Eva S., 2008, "Mortgage Market Maturity and Homeownership Inequality among Young Households: A Five-country Perspective," Research Discussion Papers No. 778, German Institute for Economic, Berlin.

Bostic, R., and K. Lee, 2008, "Mortgages, Risk, and Homeownership among Low- and Moderate-Income Families," American Economic Review, Vol. 98, No. 2, pp. 310-14.

Caldera Sánchez, A., and A. Johansson, 2011, “The Price Responsiveness of Housing Supply in OECD Countries,” OECD Economics Department Working Paper No. 837, OECD Publishing, Paris.

Cerutti, E., S. Claessens, and L. Laeven, 2015, "The Use and Effectiveness of Macroprudential Policies: New Evidence,” IMF Working Paper 15/61, International Monetary Fund, Washington.

Chambers, M., C. Garriga, and D. Schlagenhauf, 2009, “Accounting for Changes in the Homeownership Rate,” International Economic Review, Vol. 50, No. 3, pp. 677-726. 
Chiuri, M., and T. Japelli, 2003, "Financial Market Imperfections and Home Ownership: A Comparative Study," European Economic Review, Vol. 47, No. 5, pp. 857-75.

Claessens, S., A. Kose, and M. E. Terrones, 2009, "What Happens During Recessions, Crunches and Busts?" Economic Policy, Vol. 24, No. 60, pp. 653-700.

Cornett, M., J. McNutt, and P. Strahan, 2011, "Liquidity Risk Management and Credit Supply in the Financial Crisis," Journal of Financial Economics, Vol. 101, No. 2, pp 297-312.

Crowe, C., G. Dell'Ariccia, D. Igan, P. Rabanal, and H. Tong, 2011, "Policies for Macroprudential Stability: Options to Deal with Real-Estate Booms," IMF Staff Discussion Note 11/02, International Monetary Fund, Washington.

— , 2012, "How to Deal with Real-Estate Booms: Lessons from Country Experiences," Journal of Financial Stability, Vol. 9, No. 3, pp. 300-19.

Dagher, J., and K. Kazimov, 2012, Banks' Liability Structure and Mortgage Lending during the Financial Crisis, IMF Working Paper 12/155, International Monetary Fund, Washington.

Dagher, J., and N. Fu, 2011, "What Fuels the Boom Drives the Bust: Regulation and the Mortgage Crisis,” IMF Working Paper 11/25, International Monetary Fund, Washington.

Dell'Ariccia, G., D. Igan, L. Laeven, and H. Tong, 2012, "Policies for Macrofinancial Stability: How to Deal with Credit Booms," IMF Staff Discussion Note 12/06, International Monetary Fund, Washington.

Dietz, R., and D. Haurin, 2003, “The Social and Private Micro-level Consequences of Homeownership," Journal of Urban Economics, Vol. 54, No. 3, pp. 401-50.

DiPasquale, D., and E. Glaeser, 1999, "Incentives and Social Capital: Are Homeowners Better Citizens?” Journal of Urban Economics, Vol. 45, No. 2, pp. 354-84.

Drehmann, M., and M. Juselius, 2013, "Evaluating Early Warning Indicators of Banking Crises: Satisfying Policy Requirements," BIS Working Paper No. 241, Bank for International Settlements, Basel.

Duygan-Bump, B., and C. Grant, 2008, "Household Bankruptcy Decision: The Role of Social Stigma vs. Information Sharing," Federal Reserve Bank of Boston, Boston.

Fernandez-Val, I., 2009, "Fixed Effects Estimation of Structural Parameters and Marginal Effects in Panel Probit Models," Journal of Econometrics, Vol. 150, No. 1, pp. 71-85.

Ferrero, A., 2012, "House-price Booms, Current Account Deficits, and Low Interest Rates," Federal Reserve Bank of New York Staff Report No. 541, New York.

Gilchrist, S., and E. Zakrajsek, 2008, "Linkages between the Financial and Real Sectors: An Overview," Unpublished.

Gourinchas, P., R. Valdes, and O. Landerretche, 2001, "Lending Booms: Latin America and the World," Journal of LACEA Economia, LACEA - Latin American and Caribbean Economic Association, Bogotá. 
Gramlich, E., 2007, Subprime Mortgages the latest Boom and Bust. Washington: Urban Institute Press.

Hahm, J., H.S. Shin, and K. Shin, 2011, "Non-core Bank Liabilities and Financial Vulnerabilities," Federal Reserve Board of Governors and the Journal of Money, Credit and Banking Conference on Regulation of Systemic Risk, Washington, D.C., September 15-16.

Iacoviello, M., 2005, "House Prices, Borrowing Constraints, and Monetary Policy in the Business Cycle," The American Economic Review, Vol. 95, No. 3, pp. 739-64.

International Monetary Fund, 2008, "The Changing Housing Cycle and the Implications for Monetary Policy," World Economic Outlook, Chapter 3, April, pp. 103-30.

__, 2009, "Canada: 2009 Article IV Consultation-Staff Report," IMF Country Report No. 09/162, Washington.

—_, 2011, "Housing Finance and Financial Stability-Back to Basics?” Global Financial Stability Report, Chapter 3, April, pp. 111-57.

—_, 2013a, "Nordic Regional Report: 2013 Cluster Consultation,” IMF Country Report No. 13/274, Washington.

— , 2013b, “The Interaction of Monetary and Macroprudential Policies," IMF Policy Paper, Washington.

Kiyotaki, N., and J. Moore, 1997, “Credit Cycle,” Journal of Political Economy, Vol. 105, No. 2, pp. 211-48.

Li, W., and F. Yang, 2010, “American Dream or American Obsession? The Economic Benefits and Costs of Homeownership,” Business Review, Federal Reserve Bank of Philadelphia.

Mendoza, E., and M. Terrones, 2008, “An Anatomy of Credit Booms: Evidence from Macro Aggregates and Micro Data,” NBER Working Paper No. 14049, National Bureau of Economic Research, Cambridge, Massachusetts.

Mian, A., and A. Sufi, 2011, "House Prices, Home Equity-Based Borrowing, and the U.S. Household Leverage Crisis.” American Economic Review, Vol. 101, No. 5, pp. 2132-56.

Muellbauer J., and A. Murphy, 1997, "Booms and Busts in the U.K. Housing Market," The Economic Journal, Vol. 107, No. 445, pp. 1701-727.

Ortalo-Magne, F., and S. Rady, 2006, "Housing Market Dynamics: On the Contribution of Income Shocks and Credit Constraints," Review of Economic Studies, Vol. 73, No. 2, pp. 459-85.

Quint, D., and P. Rabanal, 2014, "Monetary and Macroprudential Policy in an Estimated DSGE Model of the Euro Area," International Journal of Central Banking, Vol. 10, Vol. 2, pp. 169-236. 
Rohe, W., and M. Lindblad, 2013, "Reexamining the Social Benefits of Homeownership after the Housing Crisis," Joint Center for Housing Studies, Harvard University, Cambridge, Massachusetts.

Saiz, A., 2010, "The Geographic Determinants of Housing Supply," The Quarterly Journal of Economics, Vol. 125, No. 3, pp. 1253-96.

Warnock, V., and F. Warnock, 2008, "Markets and Housing Finance," Journal of Housing Economics, Vol. 17, No. 3, pp. 239-51.

__ 2012, "Developing Housing Finance Systems," Reserve Bank of Australia Annual Conference Volume, Reserve Bank of Australia, Sydney. 
Annex I —Data Sources and House Finance Characteristics

Table A1.1 - Data Sources and Period Coverage

\begin{tabular}{|c|c|c|c|c|c|c|c|c|}
\hline & \multicolumn{2}{|c|}{ Household credit } & \multicolumn{2}{|c|}{ Private credit } & \multicolumn{2}{|c|}{ Mortgage } & \multicolumn{2}{|c|}{ House price } \\
\hline & Period & Source & Period & Source & Period & Source & Period & Source \\
\hline Argentina & 88Q1-11Q4 & other & 88Q1-11Q4 & BIS & 94Q1-11Q4 & other & $88 Q 1-11 Q 4$ & GPG \\
\hline Australia & 70Q1-12Q3 & BIS & 70Q1-12Q3 & BIS & 90Q1-12Q3 & Haver & 70Q1-12Q3 & OECD \\
\hline Austria & 00Q1-12Q3 & BIS & 00Q1-12Q3 & BIS & 01Q3-12Q3 & Haver & 00Q1-12Q3 & OECD \\
\hline Belgium & $70 Q 4-12 Q 3$ & BIS & 70Q4-12Q3 & BIS & $92 Q 4-12 Q 3$ & Haver & $70 Q 4-12 Q 3$ & OECD \\
\hline Brazil & 01Q1-12Q3 & other & 01Q1-12Q3 & BIS & 05Q1-12Q3 & other & 01Q1-12Q3 & other \\
\hline Bulgaria & $95 Q 4-12 Q 4$ & other & $95 Q 4-12 Q 4$ & other & $95 Q 4-12 Q 4$ & other & $95 Q 4-12 Q 4$ & GPG \\
\hline Canada & 70Q1-12Q3 & BIS & 70Q1-12Q3 & BIS & $70 Q 1-12 Q 3$ & Haver & $70 Q 1-12 Q 3$ & OECD \\
\hline China & 03Q1-12Q3 & BIS & 03Q1-12Q3 & BIS & 04Q3-12Q3 & Haver & 03Q1-12Q3 & GPG \\
\hline Colombia & $02 Q 3-12 Q 2$ & other & 02Q3-12Q2 & other & 02Q3-12Q2 & other & $02 Q 3-12 Q 2$ & GPG \\
\hline Croatia & $96 Q 2-12 Q 4$ & Haver & 96Q2-12Q4 & Haver & $99 Q 3-12 Q 4$ & Haver & $96 Q 2-12 Q 4$ & GPG \\
\hline Cyprus & 06Q1-12Q2 & Haver & 06Q1-12Q2 & Haver & 06Q1-12Q2 & Haver & 06Q1-12Q2 & GPG \\
\hline CzechRepublic & 99Q1-12Q1 & BIS & 99Q1-12Q1 & BIS & 99Q1-12Q1 & Haver & 99Q1-12Q1 & GPG \\
\hline Denmark & 70Q1-12Q3 & BIS & $70 Q 1-12 Q 3$ & BIS & $93 Q 1-12 Q 3$ & Haver & 70Q1-12Q3 & OECD \\
\hline Estonia & 03Q3-12Q4 & Haver & 03Q3-12Q4 & Haver & 03Q3-12Q4 & Haver & 03Q3-12Q4 & OECD \\
\hline Finland & $70 Q 4-12 Q 3$ & BIS & $70 Q 4-12 Q 3$ & BIS & 03Q1-12Q3 & other & $70 Q 4-12 Q 3$ & OECD \\
\hline France & 70Q1-12Q3 & BIS & 70Q1-12Q3 & BIS & $93 Q 1-12 Q 3$ & Haver & 70Q1-12Q3 & OECD \\
\hline Germany & 70Q1-12Q2 & BIS & 70Q1-12Q2 & BIS & $70 Q 1-12 Q 2$ & Haver & 70Q1-12Q2 & OECD \\
\hline Greece & 97Q1-12Q2 & BIS & 97Q1-12Q2 & BIS & $97 Q 1-12 Q 2$ & Haver & 97Q1-12Q2 & OECD \\
\hline HongKong & 93Q1-12Q3 & BIS & $93 Q 1-12 Q 3$ & BIS & $96 Q 2-12 Q 3$ & other & 93Q1-12Q3 & GPG \\
\hline Hungary & 98Q1-12Q2 & BIS & 98Q1-12Q2 & BIS & $00 Q 1-12 Q 2$ & Haver & 98Q1-12Q2 & GPG \\
\hline Iceland & 03Q3-12Q4 & Haver & 03Q3-12Q4 & Haver & 08Q3-12Q4 & Haver (annual) & 03Q3-12Q4 & GPG \\
\hline India & $01 Q 4-12 Q 3$ & BIS & $01 Q 4-12 Q 3$ & $\mathrm{BIS}$ & $02 Q 3-11 Q 4$ & Haver (annual) & 01Q4-12Q3 & GPG \\
\hline Indonesia & 90Q1-12Q3 & BIS & 90Q1-12Q3 & BIS & 11Q1-12Q3 & other & 90Q1-12Q3 & GPG \\
\hline Ireland & $71 Q 2-12 Q 3$ & BIS & 71Q2-12Q3 & BIS & 03Q1-12Q3 & Haver & $71 Q 2-12 Q 3$ & OECD \\
\hline Israel & $99 Q 4-12 Q 4$ & Haver & 99Q4-12Q4 & Haver & $99 Q 4-12 Q 4$ & Haver & $9904-12 Q 4$ & GPG \\
\hline Italy & 70Q1-12Q3 & BIS & 70Q1-12Q3 & BIS & $98 Q 2-12 Q 3$ & Haver & 70Q1-12Q3 & OECD \\
\hline Japan & 70Q1-12Q3 & BIS & 70Q1-12Q3 & BIS & $75 Q 4-12 Q 3$ & Haver & 70Q1-12Q3 & OECD \\
\hline Latvia & 04Q1-12Q4 & Haver & 04Q1-12Q4 & Haver & 04Q1-12Q4 & Haver & 04Q1-12Q4 & GPG \\
\hline Lithuania & 94Q1-12Q4 & Haver & 94Q1-12Q4 & Haver & 04Q1-12Q4 & Haver & 94Q1-12Q4 & GPG \\
\hline Luxembourg & 05Q1-12Q3 & BIS & 05Q1-12Q3 & BIS & 05Q1-12Q3 & Haver & 05Q1-12Q3 & GPG \\
\hline Malaysia & 00Q1-12Q3 & Haver & 00Q1-12Q3 & BIS & $00 Q 1-12 Q 3$ & Haver & 00Q1-12Q3 & GPG \\
\hline Malta & 03Q4-12Q3 & Haver & 03Q4-12Q3 & Haver & $03 Q 4-12 Q 3$ & Haver & 03Q4-12Q3 & GPG \\
\hline Mexico & 05Q1-12Q3 & BIS & 05Q1-12Q3 & BIS & 05Q1-12Q3 & other & 05Q1-12Q3 & GPG \\
\hline Netherlands & 70Q1-12Q2 & BIS & 70Q1-12Q2 & BIS & 03Q1-12Q2 & Haver & 70Q1-12Q2 & OECD \\
\hline NewZealand & 70Q1-11Q2 & other & 70Q1-11Q2 & IFS & $98 Q 2-11 Q 2$ & other & 70Q1-11Q2 & OECD \\
\hline Norway & 70Q1-12Q3 & BIS & 70Q1-12Q3 & BIS & 97Q1-11Q4 & Haver & 70Q1-12Q3 & OECD \\
\hline Philippines & 00Q1-12Q4 & other & 00Q1-12Q4 & other & 00Q1-12Q4 & other & 00Q1-12Q4 & GPG \\
\hline Poland & 04Q1-12Q3 & BIS & 04Q1-12Q3 & BIS & 04Q1-12Q3 & Haver & 04Q1-12Q3 & other \\
\hline Portugal & 88Q1-12Q3 & BIS & 88Q1-12Q3 & BIS & 07Q4-12Q3 & other & 88Q1-12Q3 & OECD \\
\hline Russia & 00Q1-11Q4 & other & 00Q1-11Q4 & BIS & 05Q4-11Q4 & other & 00Q1-11Q4 & GPG \\
\hline Singapore & 91Q1-12Q3 & BIS & $91 Q 1-12 Q 3$ & BIS & 91Q1-12Q3 & other & $91 Q 1-12 Q 3$ & GPG \\
\hline Slovenia & 04Q1-12Q4 & Haver & 04Q1-12Q4 & Haver & 04Q1-12Q4 & Haver & 04Q1-12Q4 & OECD \\
\hline SouthAfrica & 80Q1-12Q3 & BIS & 80Q1-12Q3 & BIS & 80Q1-12Q3 & Haver & 80Q1-12Q3 & GPG \\
\hline SouthKorea & 86Q1-12Q3 & BIS & 86Q1-12Q3 & BIS & $05 Q 4-12 Q 3$ & Haver & 86Q1-12Q3 & OECD \\
\hline Spain & 71Q1-12Q3 & BIS & 71Q1-12Q3 & BIS & $92 Q 4-12 Q 3$ & Haver & 71Q1-12Q3 & OECD \\
\hline Sweden & 70Q1-12Q3 & BIS & 70Q1-12Q3 & BIS & 01Q4-12Q3 & other & 70Q1-12Q3 & OECD \\
\hline Switzerland & $75 Q 2-12 Q 3$ & BIS & $75 Q 2-12 Q 3$ & BIS & 85Q2-12Q3 & Haver & $75 Q 2-12 Q 3$ & OECD \\
\hline Thailand & 91Q1-12Q3 & BIS & 91Q1-12Q3 & BIS & $03 Q 4-12 Q 3$ & Haver & 91Q1-12Q3 & GPG \\
\hline Turkey & 07Q2-12Q3 & BIS & 07Q2-12Q3 & BIS & 07Q2-12Q3 & Haver & 07Q2-12Q3 & GPG \\
\hline UK & 70Q1-12Q3 & BIS & 70Q1-12Q3 & BIS & 87Q1-12Q3 & Haver & 70Q1-12Q3 & OECD \\
\hline Ukraine & 01Q1-12Q4 & Haver & 01Q1-12Q4 & Haver & 06Q1-12Q4 & Haver & 01Q1-12Q4 & GPG \\
\hline Uruguay & 99Q2-11Q2 & other & 99Q2-11Q2 & other & & & $99 Q 2-11 Q 2$ & GPG \\
\hline USA & 70Q1-12Q3 & BIS & $70 Q 1-12 Q 3$ & BIS & $70 Q 1-12 Q 3$ & Haver & $70 Q 1-12 Q 3$ & OECD \\
\hline
\end{tabular}


Table A1.2 - Institutional and House Finance Characteristics

\begin{tabular}{|c|c|c|c|c|c|c|c|c|c|}
\hline country & $\begin{array}{l}\text { Legal } \\
\text { Right } \\
\text { Index } \\
\end{array}$ & $\begin{array}{c}\text { Credit } \\
\text { Info. } \\
\text { Index }\end{array}$ & $\begin{array}{c}\text { Cost of } \\
\text { Registering } \\
\text { Property }\end{array}$ & MaxLTV & $\begin{array}{l}\text { Term to } \\
\text { Maturity }\end{array}$ & $\begin{array}{c}\text { Tax } \\
\text { Deduction } \\
\end{array}$ & $\begin{array}{c}\text { Full } \\
\text { Recourse }\end{array}$ & $\begin{array}{c}\text { Interest } \\
\text { Type }\end{array}$ & Retail Funding \\
\hline Argentina & 4 & 6 & 7 & 80 & 20 & Yes & No & Variable & Retail Deposit \\
\hline Australia & 9 & 5 & 5 & 100 & 25 & No & Yes & Variable & Other \\
\hline Austria & 7 & 6 & 4.5 & 80 & 25 & No & Yes & Fixed & Retail Deposit \\
\hline Belgium & 6 & 4 & 12.7 & 100 & 20 & Yes & Yes & Fixed & Retail Deposit \\
\hline Brazil & 3 & 5 & 2.7 & 90 & 25 & No & No & Fixed & Retail Deposit \\
\hline Bulgaria & 8 & 6 & 3 & 81 & 15 & No & Yes & Variable & Retail Deposit \\
\hline Canada & 7 & 6 & 1.8 & 95 & 25 & No & Yes & Mixed & Retail Deposit \\
\hline China & 6 & 4 & 3.6 & 80 & 15 & No & No & Variable & Retail Deposit \\
\hline Colombia & 5 & 5 & 2 & 70 & 15 & Yes & Yes & Fixed & Other \\
\hline Croatia & 7 & 4 & 5 & 50 & 30 & Yes & Yes & Mixed & Retail Deposit \\
\hline Cyprus & 9 & 2 & 9.7 & 80 & 30 & No & No & Mixed & Retail Deposit \\
\hline CzechRepub & 6 & 5 & 3 & 100 & 20 & Yes & Yes & Mixed & Retail Deposit \\
\hline Denmark & 9 & 4 & 0.6 & 80 & 30 & Yes & Yes & Mixed & Other \\
\hline Estonia & 7 & 5 & 0.5 & 90 & 30 & Yes & Yes & Variable & Retail Deposit \\
\hline Finland & 8 & 4 & 4 & 80 & 20 & Yes & Yes & Variable & Retail Deposit \\
\hline France & 7 & 4 & 6.1 & 100 & 20 & No & Yes & Fixed & Retail Deposit \\
\hline Germany & 7 & 6 & 5.1 & 80 & 15 & No & Yes & Fixed & Retail Deposit \\
\hline Greece & 4 & 5 & 12 & 80 & 15 & Yes & Yes & Variable & Retail Deposit \\
\hline HongKong & 10 & 5 & 4.2 & 70 & 15 & No & Yes & Variable & Other \\
\hline Hungary & 7 & 5 & 5 & 70 & 20 & No & Yes & Mixed & Other \\
\hline Iceland & 7 & 5 & 2.4 & 100 & 40 & Yes & Yes & Fixed & Retail Deposit \\
\hline India & 8 & 5 & 7.4 & 110 & 20 & Yes & No & Mixed & Retail Deposit \\
\hline Indonesia & 3 & 4 & 10.9 & 90 & 20 & No & No & Variable & Retail Deposit \\
\hline Ireland & 9 & 5 & 6.3 & 100 & 40 & Yes & Yes & Mixed & Retail Deposit \\
\hline Israel & 9 & 5 & 7.3 & 95 & 20 & No & Yes & Mixed & Retail Deposit \\
\hline Italy & 3 & 5 & 4.6 & 80 & 22 & Yes & Yes & Variable & Retail Deposit \\
\hline Japan & 7 & 6 & 5.5 & 80 & 30 & Yes & Yes & Mixed & Retail Deposit \\
\hline Latvia & 10 & 5 & 2 & 100 & 30 & No & Yes & Variable & Retail Deposit \\
\hline Lithuania & 5 & 6 & 0.8 & 100 & 25 & Yes & Yes & Variable & Retail Deposit \\
\hline Luxembourg & 5 & 0 & 10.1 & 80 & 25 & Yes & Yes & Variable & Retail Deposit \\
\hline Malaysia & 10 & 6 & 3.2 & 80 & 35 & Yes & No & Variable & Retail Deposit \\
\hline Malta & 3 & 0 & 5.2 & 80 & 30 & No & Yes & Fixed & Retail Deposit \\
\hline Mexico & 5 & 6 & 5.3 & 100 & 25 & Yes & No & Variable & Other \\
\hline Netherlands & 6 & 5 & 6.1 & 125 & 30 & Yes & Yes & Fixed & Retail Deposit \\
\hline NewZealanc & 10 & 5 & 0.1 & 85 & 30 & No & Yes & Variable & Retail Deposit \\
\hline Norway & 6 & 4 & 2.5 & 85 & 20 & Yes & Yes & Variable & Retail Deposit \\
\hline Philippines & 4 & 3 & 4.8 & 80 & 30 & No & Yes & Variable & Other \\
\hline Poland & 9 & 6 & 0.4 & 100 & 32.5 & Yes & Yes & Variable & Retail Deposit \\
\hline Portugal & 3 & 5 & 7.4 & 90 & 30 & Yes & No & Variable & Retail Deposit \\
\hline Russia & 3 & 5 & 0.1 & 100 & 20 & Yes & Yes & Mixed & Retail Deposit \\
\hline Singapore & 10 & 4 & 2.9 & 80 & 35 & Yes & Yes & Variable & Other \\
\hline Slovenia & 4 & 4 & 2.1 & 70 & 10 & No & Yes & Variable & Retail Deposit \\
\hline SouthAfrica & 10 & 6 & 8.8 & 100 & 30 & No & Yes & Variable & Other \\
\hline SouthKorea & 8 & 6 & 5.1 & 70 & 20 & Yes & No & Variable & Retail Deposit \\
\hline Spain & 6 & 5 & 7.1 & 100 & 20 & Yes & Yes & Variable & Retail Deposit \\
\hline Sweden & 8 & 4 & 3 & 95 & 45 & Yes & Yes & Variable & Other \\
\hline Switzerland & 8 & 5 & 0.4 & 80 & 20 & Yes & Yes & Fixed & Other \\
\hline Thailand & 5 & 5 & 4.3 & 100 & 20 & Yes & Yes & Mixed & Retail Deposit \\
\hline Turkey & 4 & 5 & 3 & 75 & 7.5 & No & Yes & Fixed & Retail Deposit \\
\hline UK & 10 & 6 & 4.7 & 110 & 25 & No & Yes & Variable & Retail Deposit \\
\hline USA & 9 & 6 & 0.5 & 100 & 30 & Yes & No & Mixed & Other \\
\hline Ukraine & 9 & 4 & 4.1 & 100 & 20 & Yes & No & Fixed & Other \\
\hline Uruguay & 4 & 6 & 7.1 & 70 & 25 & No & Yes & Variable & Retail Deposit \\
\hline
\end{tabular}




\section{Annex II: Mortgage Market Depth and Institutional, Macroeconomic and Housing Finance Factors}

This Annex studies the correlation between countries' mortgage market depth and institutional, macroeconomic and housing finance factors. More specifically, it presents results from variations on the following cross-sectional regression:

$$
\frac{\mathrm{MC}}{\mathrm{Y}_{\mathrm{i}}}=\alpha+\beta \text { Institutions }_{\mathrm{i}}+\gamma \text { Macro }_{\mathrm{i}}+\delta \text { Housing Finance }_{\mathrm{i}}+\epsilon_{\mathrm{i}}
$$

in which $\frac{\mathrm{MC}}{\mathrm{Y}}$ is the ratio of mortgage credit to GDP. The institutional variables include: the legal-rights index, the credit-information index, and the ease-of-registering property index from the World Bank's Doing Business database. All these variables are 2001-05 averages. The macroeconomic variables include the average GDP per capital (in $\log$ ) and volatility of inflation over the same sample period. The housing finance variables captures the characteristics discussed in Section II.B (see also Table A1.2) and include: a dummy indicating whether interest payments are tax deductible, the maximum observed LTV, a dummy indicating whether there is full recourse on mortgage debt, a variable ranging from 1 to 3 increasing in the popularity of fixed-rate mortgages (vs. variable rate), the maturity of a typical mortgage contract (in years), and a dummy variable indicating whether mortgage lending is dominated by retail funded institutions.

The first column of Table 1 introduces the institutional variables. It shows that the legal rights index is a variable very significantly associated with a deeper mortgage market. The second column adds macro variables as controls. Not surprisingly, higher GDP per capital is strongly and significantly associated with deeper mortgage markets. Also there is evidence that the ease of registering a property is associated with deeper mortgage markets.

Columns (3) to (10) introduce the housing finance characteristics. The results are suggestive of a positive relationship between maximum observed LTV and the size of the mortgage market (see column 4 and the robust regression results in column 10). From a theoretical standpoint, an increase in the maximum LTV would, everything else constant, increase the total stock of mortgages, through both an intensive margin effect (larger mortgages) and an extensive margin effect (increasing the demand for loans). Obviously, the relationship goes also in the other direction, with deeper mortgage markets potentially allowing greater LTV ratios.

The typical duration of mortgage contracts is positively correlated with the depth of the mortgage market (column 7), but this result is not robust. Finally, countries where the main originators are banks that fund themselves primarily with retail deposits have significantly lower mortgage to GDP ratios (column 8). Non-retail sources of funds may help alleviate a bank's liquidity and maturity mismatch problems related to mortgage lending. Indeed they have also been linked to higher leverage in the banking sector (see Hahm, Shin, and Shin 2011).

In summary, although it is difficult to attribute a definitive causal interpretation to these regressions, housing finance characteristics - LTV, term to maturity, and funding model- 
contribute to explaining about an additional 10 percent of the cross-country variation in the depth of mortgage markets relative to a specification based solely on institutional and macro variables.

Table A2.1: OLS Regressions of Mortgage Credit to GDP on Institutional and Other Variables

\begin{tabular}{|c|c|c|c|c|c|c|c|c|c|c|}
\hline & (1) & $(2)$ & (3) & (4) & $(5)$ & (6) & (7) & (8) & (9) & $(10)$ \\
\hline Legal rights index & $\begin{array}{c}4.175 * * * \\
(0.003)\end{array}$ & $\begin{array}{l}2.190^{*} \\
(0.052)\end{array}$ & $\begin{array}{l}2.249^{*} \\
(0.053)\end{array}$ & $\begin{array}{l}2.128^{*} \\
(0.054)\end{array}$ & $\begin{array}{l}2.284^{* *} \\
(0.042)\end{array}$ & $\begin{array}{l}2.417^{* *} \\
(0.035)\end{array}$ & $\begin{array}{c}1.747 \\
(0.116)\end{array}$ & $\begin{array}{c}1.751 \\
(0.117)\end{array}$ & $\begin{array}{c}1.488 \\
(0.196)\end{array}$ & $\begin{array}{c}1.339 \\
(0.248)\end{array}$ \\
\hline Credit info. Index & $\begin{array}{c}2.899 \\
(0.108)\end{array}$ & $\begin{array}{c}0.504 \\
(0.727)\end{array}$ & $\begin{array}{c}0.505 \\
(0.729)\end{array}$ & $\begin{array}{c}0.576 \\
(0.683)\end{array}$ & $\begin{array}{c}0.288 \\
(0.842)\end{array}$ & $\begin{array}{c}0.569 \\
(0.692)\end{array}$ & $\begin{array}{c}0.643 \\
(0.647)\end{array}$ & $\begin{array}{c}0.315 \\
(0.823)\end{array}$ & $\begin{array}{c}0.301 \\
(0.825)\end{array}$ & $\begin{array}{c}0.615 \\
(0.656)\end{array}$ \\
\hline Ease of registering property & $\begin{array}{l}0.0640 \\
(0.344)\end{array}$ & $\begin{array}{l}0.0877^{*} \\
(0.096)\end{array}$ & $\begin{array}{l}0.0878^{*} \\
(0.099)\end{array}$ & $\begin{array}{l}0.0540 \\
(0.323)\end{array}$ & $\begin{array}{l}0.0839 \\
(0.109)\end{array}$ & $\begin{array}{c}0.0885^{*} \\
(0.092)\end{array}$ & $\begin{array}{c}0.0887^{*} \\
(0.084)\end{array}$ & $\begin{array}{l}0.0805 \\
(0.118)\end{array}$ & $\begin{array}{l}0.0461 \\
(0.386)\end{array}$ & $\begin{array}{l}0.236^{* *} \\
(0.024)\end{array}$ \\
\hline Log of GDP per capita & & $\begin{array}{c}12.62^{* * *} \\
(0.000)\end{array}$ & $\begin{array}{c}12.53^{* * *} \\
(0.000)\end{array}$ & $\begin{array}{c}12.96^{* * *} \\
(0.000)\end{array}$ & $\begin{array}{c}14.06^{* * *} \\
(0.000)\end{array}$ & $\begin{array}{c}12.01^{* * *} \\
(0.000)\end{array}$ & $\begin{array}{c}12.19 * * * \\
(0.000)\end{array}$ & $\begin{array}{c}13.25^{* * *} \\
(0.000)\end{array}$ & $\begin{array}{c}14.47^{* * *} \\
(0.000)\end{array}$ & $\begin{array}{c}14.38^{* * *} \\
(0.000)\end{array}$ \\
\hline CPI volatility (90-07) & & $\begin{array}{l}-0.983 \\
(0.206)\end{array}$ & $\begin{array}{l}-0.955 \\
(0.228)\end{array}$ & $\begin{array}{l}-0.808 \\
(0.291)\end{array}$ & $\begin{array}{l}-0.922 \\
(0.233)\end{array}$ & $\begin{array}{l}-1.146 \\
(0.147)\end{array}$ & $\begin{array}{l}-0.598 \\
(0.442)\end{array}$ & $\begin{array}{l}-0.941 \\
(0.215)\end{array}$ & $\begin{array}{l}-0.624 \\
(0.413)\end{array}$ & $\begin{array}{l}-0.698 \\
(0.366)\end{array}$ \\
\hline Tax deduction & & & $\begin{array}{c}1.269 \\
(0.795)\end{array}$ & & & & & & $\begin{array}{l}-2.754 \\
(0.564)\end{array}$ & $\begin{array}{l}-4.159 \\
(0.394)\end{array}$ \\
\hline Max observed LTV & & & & $\begin{array}{l}0.319^{*} \\
(0.083)\end{array}$ & & & & & $\begin{array}{c}0.296 \\
(0.115)\end{array}$ & $\begin{array}{c}0.426^{* *} \\
(0.034)\end{array}$ \\
\hline Full recourse & & & & & $\begin{array}{l}-7.764 \\
(0.206)\end{array}$ & & & & $\begin{array}{l}-7.719 \\
(0.188)\end{array}$ & $\begin{array}{l}-9.742 \\
(0.104)\end{array}$ \\
\hline Interest type & & & & & & $\begin{array}{c}3.368 \\
(0.253)\end{array}$ & & & $\begin{array}{c}2.605 \\
(0.355)\end{array}$ & $\begin{array}{c}2.030 \\
(0.476)\end{array}$ \\
\hline Term to maturity & & & & & & & $\begin{array}{l}0.634^{*} \\
(0.056)\end{array}$ & & $\begin{array}{c}0.457 \\
(0.180)\end{array}$ & $\begin{array}{c}0.210 \\
(0.554)\end{array}$ \\
\hline Retail funding & & & & & & & & $\begin{array}{l}-9.816^{*} \\
(0.073)\end{array}$ & $\begin{array}{l}-10.48^{*} \\
(0.053)\end{array}$ & $\begin{array}{c}-10.74^{* *} \\
(0.050)\end{array}$ \\
\hline Constant & $\begin{array}{l}-9.578 \\
(0.380)\end{array}$ & $\begin{array}{c}-105.8^{* * *} \\
(0.000)\end{array}$ & $\begin{array}{c}-106.2^{* * *} \\
(0.000)\end{array}$ & $\begin{array}{c}-138.5^{* * *} \\
(0.000)\end{array}$ & $\begin{array}{c}-113.7^{* * *} \\
(0.000)\end{array}$ & $\begin{array}{c}-107.2^{* * *} \\
(0.000)\end{array}$ & $\begin{array}{c}-115.7^{* * *} \\
(0.000)\end{array}$ & $\begin{array}{c}-101.3^{* * *} \\
(0.000)\end{array}$ & $\begin{array}{c}-146.4^{* * *} \\
(0.000)\end{array}$ & $\begin{array}{c}-144.6^{* * *} \\
(0.000)\end{array}$ \\
\hline Observations & 53 & 53 & 53 & 53 & 53 & 53 & 53 & 53 & 53 & 52 \\
\hline $\mathrm{R}-\mathrm{sq}$ & 0.291 & 0.600 & 0.600 & 0.625 & 0.613 & 0.611 & 0.630 & 0.627 & 0.696 & 0.692 \\
\hline
\end{tabular}




\section{Annex III: Robustness Analysis of Booms Definitions}

This Annex explores whether the findings in this note are robust to the specific definition of boom episodes discussed in Section III.

Existing literature employs various approaches to identify credit and house-price booms and alternative thresholds. To some extent, this is more art than science. Here we compare our baseline boom episodes to the boom dummies generated by using two different filters (a backward-looking cubic trend and a Hodrick-Prescott filter) and different thresholds (separating one-quarter of the real growth rate distribution of each variable and using a minimum boom duration of six quarters instead of eight quarters). In general, the list of episodes we identify is not very sensitive to the methodology used. The major booms are captured under all methodologies. As expected, differences appear in small- and medium-sized booms where different thresholds matter more (Table A3.1).

Perhaps a more important concern is

Table A3.2 - Number of Booms and Recessions that, depending on which booms each methodology/threshold leaves out, the incidence of post-bust recessions may be different.

However, this does not seem to be a problem for our sample (see Table A3.2). The incidence of recessions remains similar across methodologies, varying in a relatively close range from 59 percent to 67 percent.

\begin{tabular}{ccc}
\hline $\begin{array}{c}\text { Boom episodes } \\
\text { identified using: }\end{array}$ & $\begin{array}{c}\text { Total number } \\
\text { of booms }\end{array}$ & $\begin{array}{c}\text { Followed by } \\
\text { recession within } \\
\text { three years of } \\
\text { boom end }\end{array}$ \\
\hline Baseline (8 quarters) & 85 & $64.1 \%$ \\
Topthird (6 quarters) & 104 & $64.2 \%$ \\
Topquarter (8 quarters) & 70 & $59.1 \%$ \\
Cubic trend (8 quarters & 87 & $67.1 \%$ \\
HP trend (8 quarters) & 89 & $66.7 \%$ \\
\hline
\end{tabular}

Note: The Number of quarters corresponds to the minimum boom duration used in each methodology. Baseline corresponds to the threshold separating top $1 / 3$ of the real growth rate distribution of each variable and using a minimum boom duration of 6 quarters. 


\section{Table A3.1 - Correlations across Different Methodologies}

Simple Correlation

House price

\begin{tabular}{|c|c|c|c|c|c|c|c|c|c|c|c|}
\hline & Top third & $\begin{array}{c}\text { Top } \\
\text { third6 }\end{array}$ & $\begin{array}{c}\text { Top } \\
\text { quarter }\end{array}$ & $\begin{array}{l}\text { Cubic } \\
\text { trend }\end{array}$ & $\begin{array}{l}\mathrm{HP} \\
\text { trend }\end{array}$ & & Top third & $\begin{array}{c}\text { Top } \\
\text { third6 }\end{array}$ & $\begin{array}{c}\text { Top } \\
\text { quarter }\end{array}$ & $\begin{array}{l}\text { Cubic } \\
\text { trend }\end{array}$ & $\begin{array}{l}\mathrm{HP} \\
\text { trend }\end{array}$ \\
\hline Baseline & 1 & & & & & Baseline & 1 & & & & \\
\hline Topthird6 & 0.939 & 1 & & & & Topthird6 & 1.000 & 1 & & & \\
\hline Topquarter & 0.802 & 0.754 & 1 & & & Topquarter & 1.000 & 1.000 & 1 & & \\
\hline Cubic trend & 0.918 & 0.883 & 0.726 & 1 & & Cubic trend & 0.994 & 0.984 & 0.955 & 1 & \\
\hline $\mathrm{HP}$ trend & 0.907 & 0.872 & 0.717 & 0.975 & 1 & $\mathrm{HP}$ trend & 0.993 & 0.981 & 0.952 & 0.999 & 1 \\
\hline \multicolumn{12}{|c|}{ Household credit } \\
\hline & Top third & $\begin{array}{c}\text { Top } \\
\text { third6 }\end{array}$ & $\begin{array}{c}\text { Top } \\
\text { quarter }\end{array}$ & $\begin{array}{l}\text { Cubic } \\
\text { trend }\end{array}$ & $\begin{array}{l}\mathrm{HP} \\
\text { trend }\end{array}$ & & Top third & $\begin{array}{c}\text { Top } \\
\text { third6 }\end{array}$ & $\begin{array}{c}\text { Top } \\
\text { quarter }\end{array}$ & $\begin{array}{l}\text { Cubic } \\
\text { trend }\end{array}$ & $\begin{array}{l}\mathrm{HP} \\
\text { trend }\end{array}$ \\
\hline Baseline & 1 & & & & & Baseline & 1 & & & & \\
\hline Topthird6 & 0.966 & 1 & & & & Topthird6 & 1.000 & 1 & & & \\
\hline Topquarter & 0.898 & 0.867 & 1 & & & Topquarter & 1.000 & 1.000 & 1 & & \\
\hline Cubic trend & 0.842 & 0.829 & 0.776 & 1 & & Cubic trend & 0.977 & 0.968 & 0.967 & 1 & \\
\hline HP trend & 0.819 & 0.836 & 0.757 & 0.844 & 1 & HP trend & 0.972 & 0.974 & 0.965 & 0.972 & 1 \\
\hline
\end{tabular}

\section{Corporate credit}

\begin{tabular}{|c|c|c|c|c|c|c|c|c|c|c|c|}
\hline & Top third & $\begin{array}{c}\text { Top } \\
\text { third66 }\end{array}$ & $\begin{array}{c}\text { Top } \\
\text { quarter }\end{array}$ & $\begin{array}{l}\text { Cubic } \\
\text { trend }\end{array}$ & $\begin{array}{l}\mathrm{HP} \\
\text { trend }\end{array}$ & & Top third & $\begin{array}{c}\text { Top } \\
\text { third6 }\end{array}$ & $\begin{array}{c}\text { Top } \\
\text { quarter }\end{array}$ & $\begin{array}{l}\text { Cubic } \\
\text { trend }\end{array}$ & $\begin{array}{l}\mathrm{HP} \\
\text { trend }\end{array}$ \\
\hline Baseline & 1 & & & & & Baseline & 1 & & & & \\
\hline Topthird6 & 0.921 & 1 & & & & Topthird6 & 1.000 & 1 & & & \\
\hline Topquarter & 0.994 & 0.915 & 1 & & & Topquarter & 1.000 & 1.000 & 1 & & \\
\hline Cubic trend & 0.825 & 0.817 & 0.820 & 1 & & Cubic trend & 0.976 & 0.964 & 0.974 & 1 & \\
\hline $\mathrm{HP}$ trend & 0.806 & 0.784 & 0.800 & 0.891 & 1 & $\mathrm{HP}$ trend & 0.972 & 0.951 & 0.971 & 0.987 & 1 \\
\hline
\end{tabular}

Private credit

\begin{tabular}{|c|c|c|c|c|c|c|c|c|c|c|c|}
\hline & Top third & $\begin{array}{c}\text { Top } \\
\text { third6 }\end{array}$ & $\begin{array}{c}\text { Top } \\
\text { quarter }\end{array}$ & $\begin{array}{l}\text { Cubic } \\
\text { trend }\end{array}$ & $\begin{array}{l}\mathrm{HP} \\
\text { trend }\end{array}$ & & Top third & $\begin{array}{c}\text { Top } \\
\text { third6 }\end{array}$ & $\begin{array}{c}\text { Top } \\
\text { quarter }\end{array}$ & $\begin{array}{l}\text { Cubic } \\
\text { trend }\end{array}$ & $\begin{array}{l}\mathrm{HP} \\
\text { trend }\end{array}$ \\
\hline Baseline & 1 & & & & & Baseline & 1 & & & & \\
\hline Topthird6 & 0.936 & 1 & & & & Topthird6 & 1.000 & 1 & & & \\
\hline Topquarter & 0.955 & 0.893 & 1 & & & Topquarter & 1.000 & 1.000 & 1 & & \\
\hline Cubic trend & 0.834 & 0.803 & 0.794 & 1 & & Cubic trend & 0.975 & 0.958 & 0.966 & 1 & \\
\hline HP trend & 0.773 & 0.753 & 0.736 & 0.879 & 1 & HP trend & 0.956 & 0.936 & 0.943 & 0.985 & 1 \\
\hline
\end{tabular}




\section{Annex IV: Credit Booms as Predictors of Housing Booms.}

This annex explores the potential predictors of housing booms, focusing on the role of credit booms. The following Probit model is estimated:

$$
(\text { housing boom }=1)_{i t}=\alpha+\beta X i t-4+\gamma Y_{t}+\theta \text { credit_boom } i t-4+\varepsilon_{i t}
$$

in which the dependent variable housing boom is a dummy equal to one when there is a realestate boom and 0 otherwise; and credit_boom corresponds to the four-quarters lag credit-boom dummy in household or private credit. The control variables include housing finance characteristics and other variables used in the housing boom literature (the log of per-capita real GDP, the level of short-term interest rates, household indebtedness, the VIX, GDP growth, CPI inflation, and the current account balance in percent of GDP).

Since the objective of the exercise is to explore the predictive power of these variables we lag all the "slow moving" regressors by four quarters. To some extent, this may also help reducing endogeneity. Yet as stated in the main text, one should use caution in interpreting the results as causal relationships. Finally, since the time dimension of the estimated panel is relatively large (about 100 observations on average), fixed-effect estimates do not suffer from the incidental parameters bias problem, so the Fernandez-Val (2009) Probit bias-corrected estimator is not necessary. ${ }^{19}$

The results are shown in Table A4, and they indicate that household-credit booms are statistically significant predictors of real-estate booms. The presence of a household-credit boom increases the probability of a real-estate boom to 57 percent against an unconditional probability of 29 percent. Across specifications, household-credit booms are better predictors of house-price booms than private-credit booms. The level of household debt to GDP, which is highly correlated with the depth of mortgage markets, is also a statistically significant predictor, but its coefficient is negative, signaling that initial high household leverage levels seem to decrease the occurrence of real-estate booms. The role of global factors simultaneously driving house-price booms across countries is also reflected in the expected negative signs of the Federal Funds rates and VIX, which are statistically significant across most specifications.

Finally, lagged GDP growth is positively associated with the probability of a real-estate boom, indicating that real-estate booms tend to start during or in the immediate aftermath of periods of buoyant economic growth. The coefficient of the current account balance is also positive and statistically significant across specifications, signaling that, on average real-estate booms have a larger probability to start during favorable external conditions. This relation clearly does not hold in all countries. While in many countries (for example, Germany and South Korea) housing booms have been associated with current account surpluses, in other countries, such as the

\footnotetext{
${ }^{19}$ Results are robust to the selection of the number of lags. In the regression without house finance characteristics we include country fixed effects in addition to the time-varying variables. Max observed LTV is the only house finance variable reported in the table because the others were not statistically significant.
} 
United States, housing booms have typically been associated with current account deficits (Ferrero, 2012).

In order to include housing finance characteristics (only available for recent years) in the regressions, one has to run estimations for the period 2000-12 without including country fixed effects. Results are similar to the full sample with respect to the importance of household-credit booms, household leverage levels, GDP growth, and current account-balance variables. Among the house financial characteristics added to the estimations, the maximum observed LTV is the only variable that is statistically significant (see column 5 in Table A4.1). The higher the maximum observed LTV, the higher the probability of a real-estate boom. This is most likely capturing the effect of relaxed lending standards on house prices, and is supported by other studies (Crowe and others, 2011; IMF 2011; Cerutti, Claessens, and Laeven, 2015) that have found a positive relationship between LTV limits and house price increases over time. Hence, to the extent that this coefficient can be given a causal interpretation, the results presented here imply that trying to reduce LTVs through LTV limits would constitute a well-targeted objective, and its effectiveness would be a function of whether such limits erode over time (for example, through regulatory arbitrage).

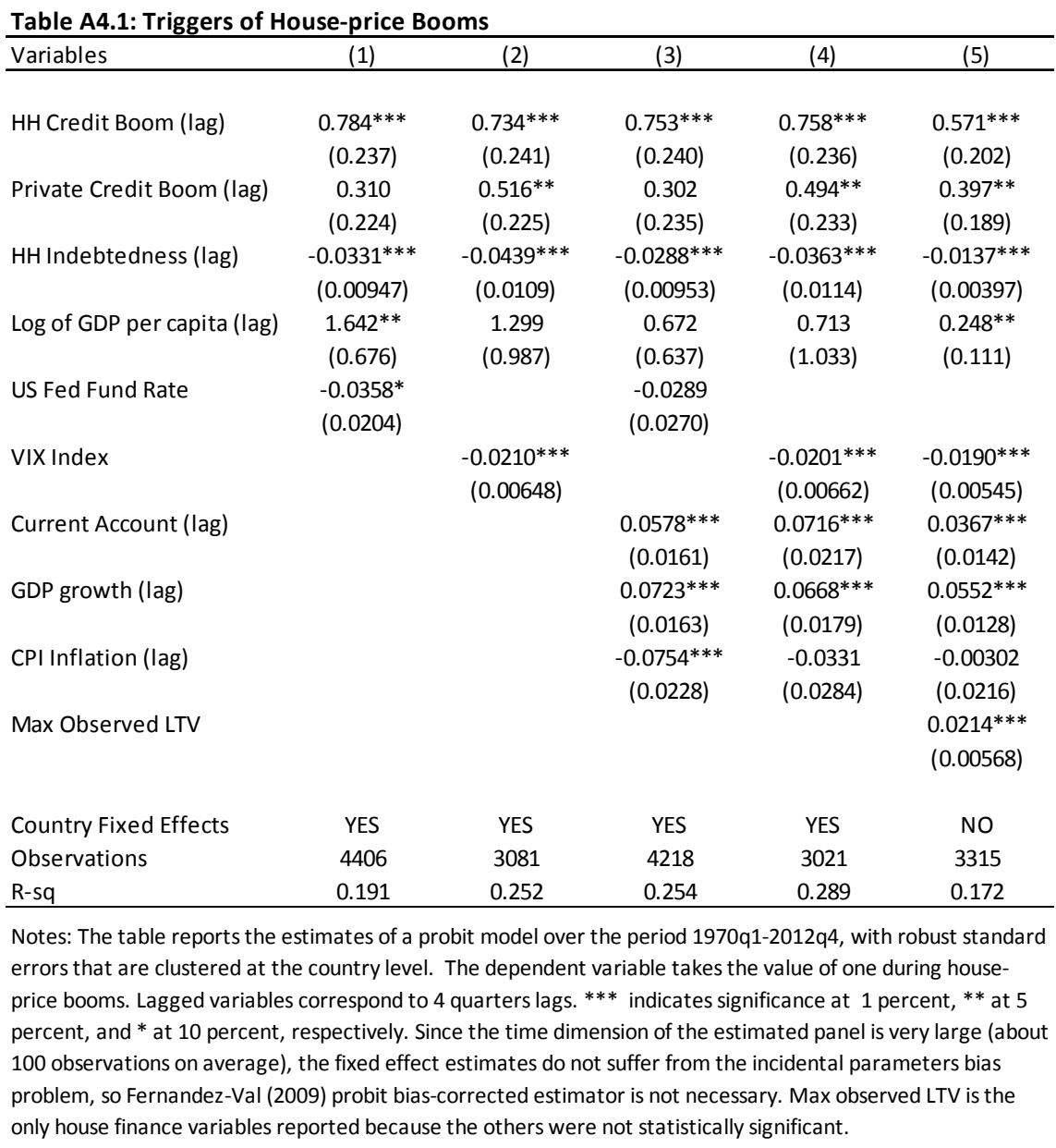




\section{Annex V: Predictors of Bad Housing Booms}

This Annex examines what factors can help predict whether a housing-price boom will lead to a recession (and possibly financial distress). We estimate the following probit model:

$$
(\text { bad housing boom }=1)_{i}=\alpha+\beta X_{i}+\theta_{1} \text { credit_boom_type_1 } 1_{i}+\theta_{2} \text { credit_boom_type_ } 2_{i}+\varepsilon_{i}
$$

in which the dependent variable, bad housing boom, is a dummy equal to one when a real-estate boom ends in a recession, and 0 otherwise; and the dummies credit_boom_type 1 and 2, provides information on the characteristics of the house-price boom based on the evolution of credit. Based on the previously defined breakdown, credit_boom_type 1 is equal to 1 for houseprice booms with only household-credit booms (Type 1), credit_boom_type 2 is equal to 1 for house-price booms with private (twin household and firm) credit booms (Type 2). As additional control variables, we include housing finance characteristics, the log of per-capita real GDP (measured at the end of the house-price boom), the duration of the house-price boom, household credit to GDP (as proxy of indebtness, measured also at the end of house-price boom), and interaction variables between the credit boom type and house finance characteristics.

The results, presented in Table A5.1, can be summarized as follows. First, the type of credit boom accompanying a real-estate boom provides some information about how the latter could end. Real-estate booms accompanied by private-credit booms are more likely to end in recessions than other types of housing booms. Second, in the interacted variables, it is clear that booms in countries that finance housing credit primarily through bank retail deposits have a lower probability of ending in recessions. Third, the coefficients of housing boom duration are not statistically significant across specifications. Finally, the higher the level of household indebtness, the higher the probability of a house-price boom ending in a recession.

\begin{tabular}{|c|c|c|c|c|c|c|}
\hline & (1) & (2) & (3) & (4) & $(5)$ & (6) \\
\hline HH Indebtedness & $\begin{array}{c}0.0110^{*} \\
(0.00665)\end{array}$ & $\begin{array}{c}0.0110^{*} \\
(0.00655)\end{array}$ & $\begin{array}{c}0.0481 * * * \\
(0.0166)\end{array}$ & $\begin{array}{c}0.0495 * * * \\
(0.0172)\end{array}$ & $\begin{array}{c}0.0510^{* *} \\
(0.0249)\end{array}$ & $\begin{array}{c}0.0545^{* * *} \\
(0.0199)\end{array}$ \\
\hline House-price boom duration & $\begin{array}{c}-0.0000182 \\
(0.0174)\end{array}$ & $\begin{array}{c}-0.0000331 \\
(0.0175)\end{array}$ & $\begin{array}{c}0.0749 \\
(0.0486)\end{array}$ & $\begin{array}{c}0.0765 \\
(0.0492)\end{array}$ & $\begin{array}{c}0.0605 \\
(0.0612)\end{array}$ & $\begin{array}{c}0.0785 \\
(0.0499)\end{array}$ \\
\hline Type 1 (with only HH credit boom) & $\begin{array}{l}-0.0137 \\
(0.512)\end{array}$ & & $\begin{array}{l}-0.327 \\
(0.853)\end{array}$ & & $\begin{array}{l}3.962^{* *} \\
(1.624)\end{array}$ & \\
\hline Type 2 (with private credit boom) & $\begin{array}{c}0.573 \\
(0.432)\end{array}$ & $\begin{array}{l}0.580^{*} \\
(0.315)\end{array}$ & $\begin{array}{l}1.992^{* *} \\
(0.814)\end{array}$ & $\begin{array}{c}2.203^{* * *} \\
(0.689)\end{array}$ & $\begin{array}{c}7.178^{* * *} \\
(1.390)\end{array}$ & $\begin{array}{c}6.870^{* * *} \\
(1.393)\end{array}$ \\
\hline Log of GDP per capita & $\begin{array}{c}0.0331 \\
(0.0747)\end{array}$ & $\begin{array}{c}0.0332 \\
(0.0750)\end{array}$ & $\begin{array}{c}0.104 \\
(0.114)\end{array}$ & $\begin{array}{c}0.103 \\
(0.110)\end{array}$ & $\begin{array}{l}0.0864 \\
(0.111)\end{array}$ & $\begin{array}{l}0.0734 \\
(0.106)\end{array}$ \\
\hline Retail funding & & & & & $\begin{array}{c}0.821 \\
(1.398)\end{array}$ & $\begin{array}{l}0.0629 \\
(1.211)\end{array}$ \\
\hline Type 1*Retail funding & & & & & $\begin{array}{c}-4.810^{* *} \\
(2.019)\end{array}$ & \\
\hline Type2*Retail funding & & & & & $\begin{array}{c}-5.715^{* * *} \\
(1.518)\end{array}$ & $\begin{array}{c}-4.727^{* * *} \\
(1.362)\end{array}$ \\
\hline Observations & 77 & 77 & 33 & 33 & 33 & 33 \\
\hline $\mathrm{R} s q$ & 0.051 & 0.051 & 0.318 & 0.314 & 0.360 & 0.347 \\
\hline
\end{tabular}

